STATE OF ALASKA

DEPARTMENT OF NATURAL RESOUTCES

\title{
THE MESHIK ARC - AN EOCENE TO EARLIEST MIOCENE MAGMATIC ARC
} ON THE ALASKA PENINSULA

By

F.H. Wilson

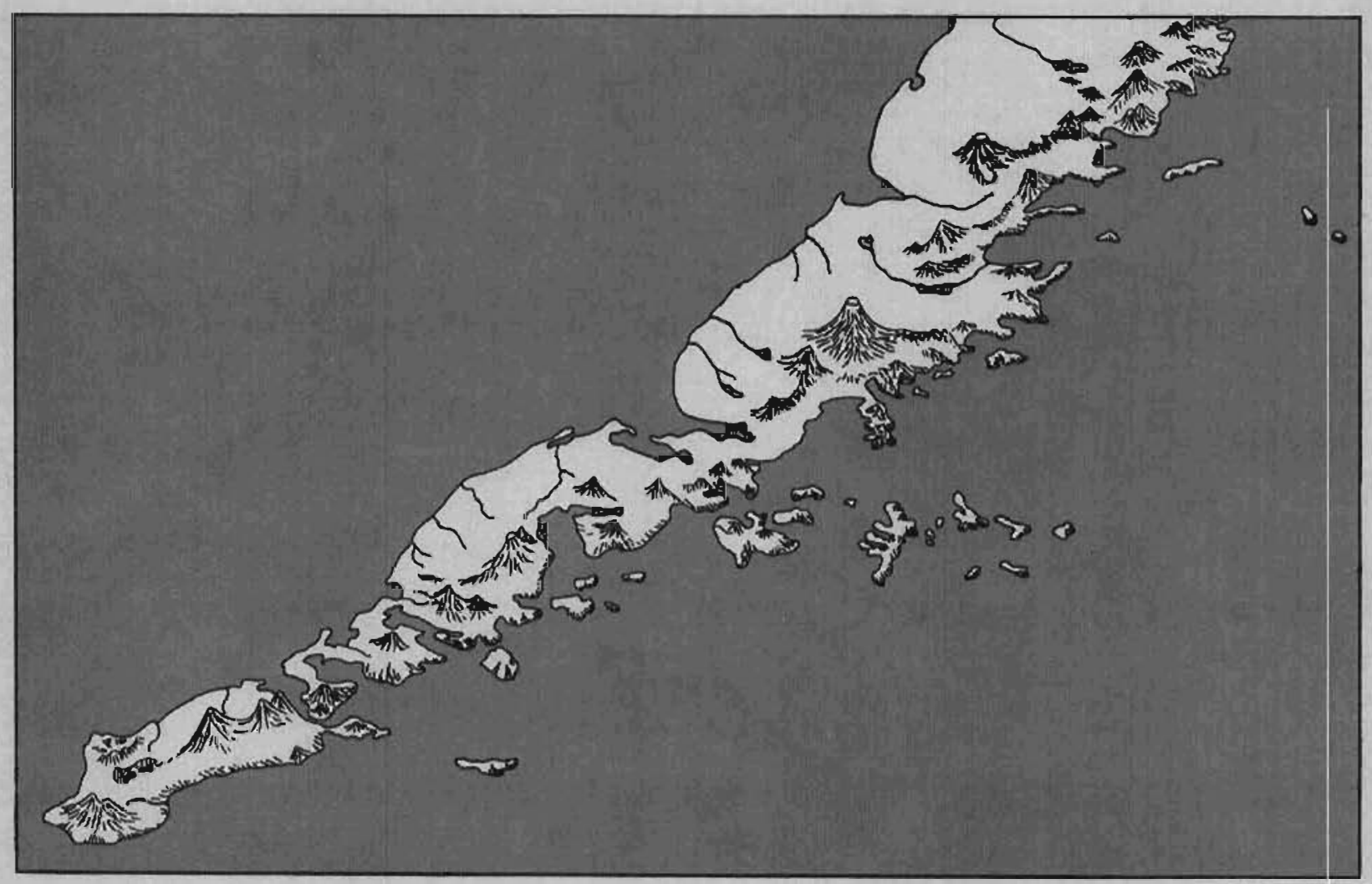

PROFESSIONAL REPORT 88

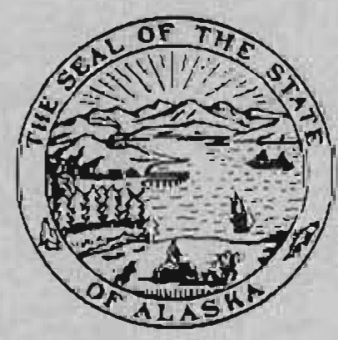

Published by

DIVISION OF GEOLOGICAL AND GEOPHYSICAL SURVEYS

ROSS G. SCHAFF

STATE GEOLOGIST

1985 
PROFESSIONAL REPORT 88

THE MESHIK ARC - AN EOCENE TO EARLIEST MIOCENE MAGMATIC ARC ON THE ALASKA PENINSULA

By

F.H. Wilson

Foirbanke, Alagkea 


\section{STATE OF ALASKA}

Bill Sheffield, Governor

Esther C. Wunnicke, Commissioner, Depl. of Natural Resources

Ross G. Schaff, Staze Geologist

DGGS publications evailable at: Alaska National Bank of the North Bldg. (2nd floor), Geist Rd. and University Ave., Falrbanks; 3601 C St. (10th Boor), Anchorage; 400 willoughby Center (4th t)oor), Juneau; and the State Oplice Bldg.. Ketcblkan. Matl orders should bo addressed to DGGS, 794 University Ave, (Besement), Fairbanks, AK 99701, Cost $\$ 2$. 


\section{CONTENTS}

Page

Abstract . . . . . . . . . . . . . . . . . . . . . . . . . .

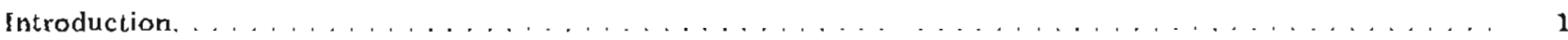

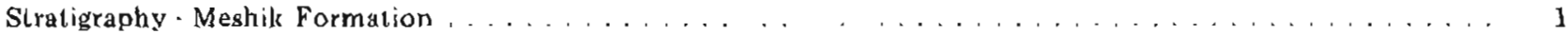

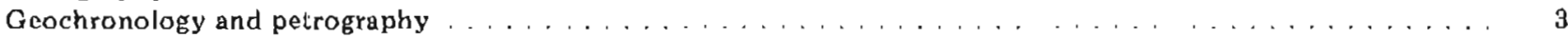

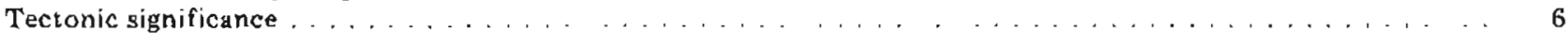

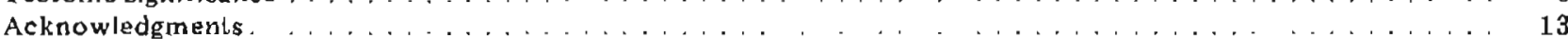

References ciled . . . . . . . . . . . . . . . . . . . . . . . . . 13

\section{FIGURES}

Figure 1. Map of the central Alaska Peninsula showing the approximale exlent of the Meshik arc rocks ......

2. Ternary diagrams showing proportions of Fe oxide $(F)$. alkali (A), and $\mathrm{Mg}$ oxide $(\mathrm{M})$ and percentage of normative quarlz (Q), orlhoclase (Or). and plagioclase (PI) for volcanic and hypabyssal rocks of the Meshik are . . . . . . . . . . . . . . . . . .

3. Schematic drawing showing orientation of lectonic elements during lale Eocene lime on the

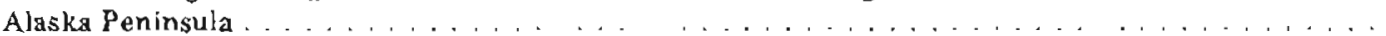

\section{TABLES}

Table 1. Bulk chemistry and normative minerals of volcanic rocks. Meshik Formation ............. 4

2. Bulk chemistry and normative minerals of Eocene-Olıgocene intrusive racks. . . . . . . . . . . . 5

3. Potassium-argon ages. Meshik arc . . . . . . . . . . . . . . . . . . . . . 8

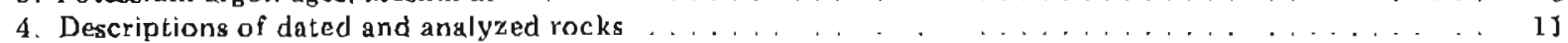




\title{
THE MESHIK ARC - AN EOCENE TO EARLIEST MIOCENE MAGMATIC ARC ON THE ALASKA PENINSULA
}

\author{
By \\ F.H. Wilson ${ }^{1}$
}

\section{ABSTRACT}

The Meshik arc is herein defined to include Eocene to earliest Mlocene volcanic and hypabyssal rocks and the associated Meshik and Stepovak Fomations of the central Alaska Peninsula. Igneous rocks range from basalt to dacite and yielded K-Ar ages of 48 to $22 \mathrm{~m}$.y. The Meshik arc is oriented along the trend of the Alaska Peninsula, subparallel to the present.day Aleutlan arc. Rocks of the Meshik arc are emplaced on Cenozoic, Mesozoic, and older clastic sedimentary rocks of the Alaska Peninsula terrane. Tectonic interpretation suggests: a) the arc represents a relatively stationary period in the otherwise mobile migration of the Alaska Penin. sula lerrane, b) subduction was an important process along the Alaska Peninsula during Tertiary time, and c) most migration of the Alaska Peninsula terrane since Crelaceous time took place in Paleocene and middle Miocene time.

\section{INTRODUCTION}

An early to middle Tertiary magmatic arc was identified during geochronologic and mapping studies on the central Alaska Peninsula (fig. 1). Though originally recognized by Burk (1965) as part of a continuous Tertlary volcanic sequence, the Meshik arc is a distinct phase in the Tertiary history of the Peninsula. The arc includes volcanic and hypabyssal rocks of basaltic to dacitic composition and inlercalated volcaniclastic Eocene to earliest Miocene sedimentary rocks of the Meshik and Stepovak Formations (Burk, 1965; Detter. man and others, 1981). Using the rock nomenclature recommended by Streckeisen (1979), whole-rock chemical analyses show that the igneous rocks range from leucobasalt to dacite (fig. 2, tables 1 and 2). K.Ar age deteminations on volcanic and hypahyssal rocks associated with the arc range from 48 to $22 \mathrm{~m}$.y., mostly within 40 to 30 m.y. (table 3 ).

The central part of the Alaska Peninsula (fig. I) is composed of mildly deformed Mesozoic clastic rocks overlain and intruded by Tertiary volcanic and intrusive

\footnotetext{
${ }^{1}$ U.S. Geological Survey, 4200 University Drive, Ancliorage, Alaska 99508-4667. Publication authorized by Director, U.S. Geological Survey.
}

rocks (Detterman and others, 1981). The Chignik anticline, an anticline overthrust to the southeast, deforms both Mesozoic and Paleogene rocks, including those of the Meshik arc (Wilson, 1980; Detterman and others, 1981\}. The Mesozoic rocks are part of a faytraveled lectonostratigraphic terrane that makes up much of the Alaska Peninsula. Upper Mesozoic flysch of che Chugach terrane lies southeast of the Alaska Penin. sula (Peninsular) terrane (Jones and olhers, 1981); southeast of this lics the active Aleutian Trench.

Burk (1965) contributed many of the original descriplions of Tertiary formations on the Alaska Peninsula; he recognized the Paleogene volcaniclastic and volcanic rocks (which lie divided into the Tolstoi, Meshik, and Stepovak Formations and identified what he thought were middle Tertiary plutons and an upper Tertiary (Pliocene) sequence of volcanic rocks.

The rocks of the Meshik arc crop out in a narrow belt on the Pacific side of the Peninsula around Chignik Bay (fig. 1). Drill holes and K-Ar dates (Brockway and others, 1975) indicate they also underlie the Alaska Peninsula part of the Nushagak - Bristol Bay Lowland of Wahrhaftig (1965).

The Meshik arc apparently extends northeastward into the vicinity of Mother Goose Lake (fig. 1). Southwest of Chignik Bay, rocks of the Meshik are may extend through the Port Moller area. Igneous rocks of similar age, which inay be related to the Meslik arc, also occur as part of the Alaska-Aleutian Range batholith (Reed and Lanphere, 1973) and on the Aleutian Islands (Wilson, 1981).

\section{STRATIGRAPHY - MESHIK FORMATION}

The Meshik Formation is a volcanic and volcaniclastic unit named by Knappen (1929, p. 198-200) from exposures soutls of Anjakchak Caldera (fig. 1); he described a sequence of reverse-graded, andesitic volcaniclastic rocks that included interbedded bentonitic clay, fine sand, volcanic ash, and coarse agglomerate. The upper part of the formation is composed entirely of coarse volcanic materials, including agglomerate and nuinerous flows (Knappen, 1929, p. 198). According to Burk (1965, p. 99), the 1.500-m-thick Meshik Formation rests conformably on the Tolstoi Formation and is 


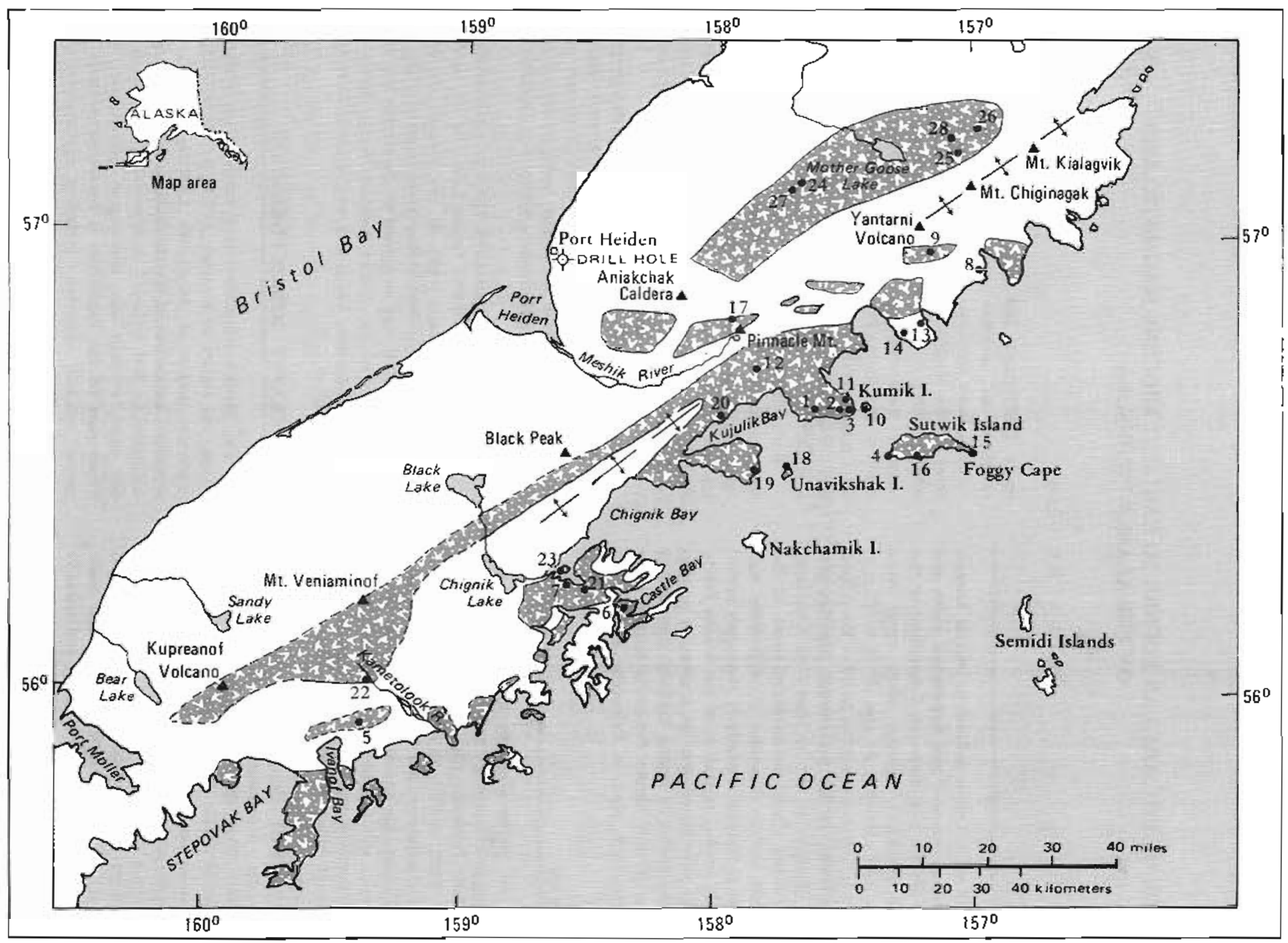

Figure 1. Map of the central Alaska Peninsula showing the approximate extent of the Meshik are rocks (in gray). Boundarjes dashed where inlerred. Numbers refer to sample data in table 4 . A drill hole at Port Heiden encountered a minimum of $1,500 \mathrm{~m}$ of Meshik Format.1on beginning at 2 , $800 \mathrm{~m}$ depth. Base modified from Alaska Environmental information Data Center 1:1,000,000-scale base-map serjes, 1981. 

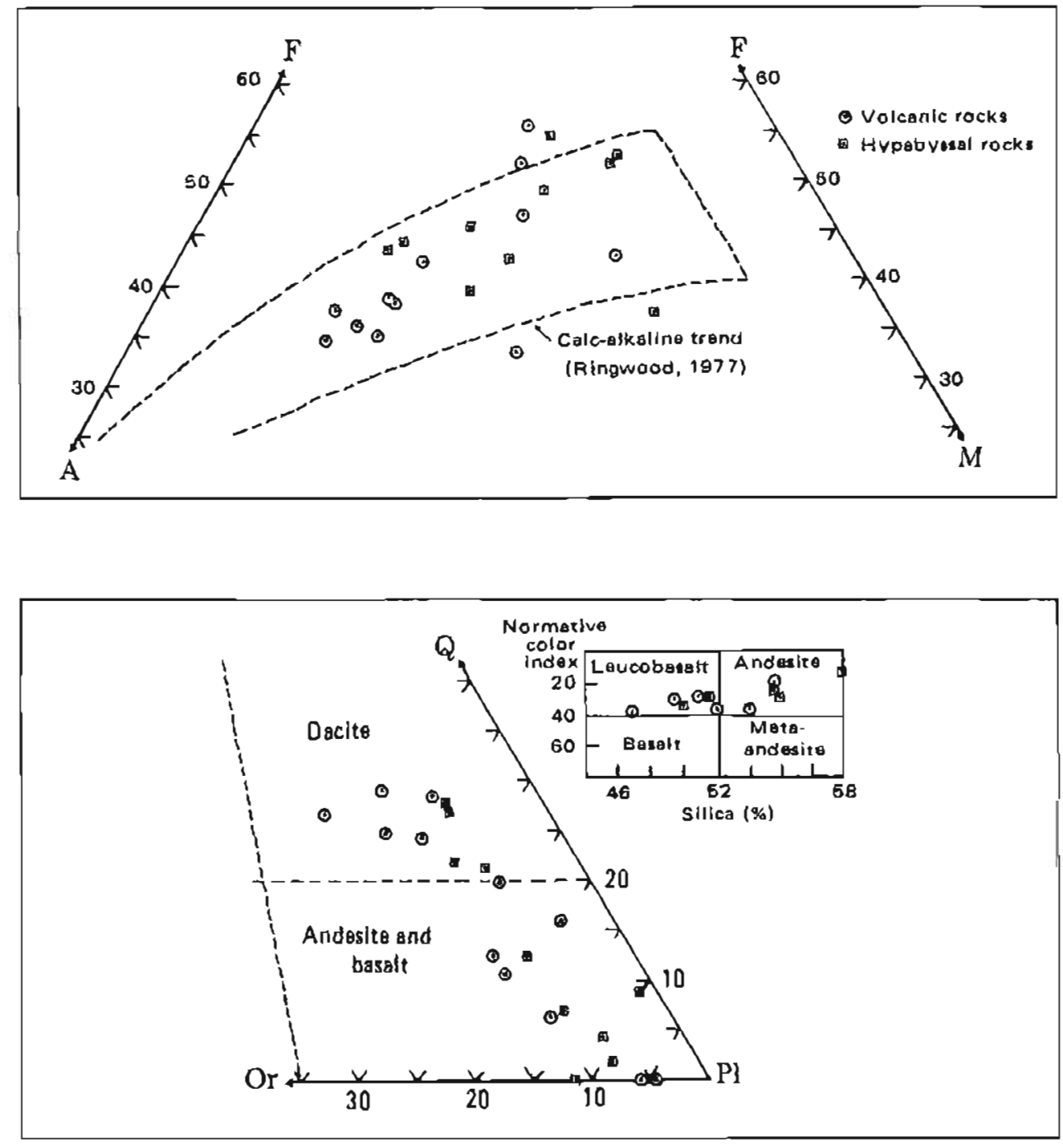

Figure 2. Ternary diagrams showing (top) proportions of Fe oxide (F), alkali (A), and $\mathrm{Mg}$ oxide $(M)$ and (bottom) percentage of normative quartz $(Q)$, orthoclase $(O r)$, and plagioclase (P)) for volcanic and hypabyssal rocks of the Meshik are.

overlain unconformably by Pliocene and younger volcanic rocks or by alluvial and glacial debris. Detterman and others (1981) assigned the Meshik Formation an Eocene to Oligocene age on the basis of plant fossils and radiometric data and described the contact with the Tolstoi Formation as unconformable.

Volcanic rocks of the Meshik Formation include dacitic to basatic flows, agglomerate, and breccis (Wilson, 1980). These are commonly hydrothermally altered and are bright red, green, or brown; fresh or only slightly altered basaltic to dacitic plugs and flows are occasionally included in the formation.

\section{GEOCHRONOLOGY AND PETROGRAPHY}

Fresh, columnar-jointed basalt, andesite, and dacite plugs intrude genetically related flows within the Meshik Formation. Some klows and plugs were K-Ar dated with whole-rock, hornblende, plagioclase, and rare biotite samples (Wilson and others, 1981). Ages range from 42 to $22 \mathrm{~m}, \mathrm{y}$. (table 3 ; Witson and others, 1981; Wilson, 1982), mostly in the $40-$ to $30-\mathrm{m} . \mathrm{y}$, bracket. Of those samples less than 30 m.y. old (table 2), some may have been thermally affected by nearby late Tertisty magmatic activity. The other young ages are from rocks from areas immediately southwest of both Chignik Bay and $\mathrm{Mt}$. Chiginagak.

Some Eocene and Oligocene intrusive rocks are found on the Alaska Peninsula and are included in the Meshik axc (as defined); they are apparently volcanic necks, similar to the plugs mentioned above, but more deeply eroded. K-Ar age determinations on these intru. sions range from 48 to $33.5 \mathrm{~m}, \mathrm{y}$, slightly more than the less eroded plugs and flows.

The following descriptions characterize the igneous rocks of the Meshik arc. Table 4 describes dated and 
analyzed rocks, which range from hormblende dacite to two-pyroxene andesite and basalt. In the andesite and basalt, phenocrystic amphibole is the dominant mafic mineral; however, a few samples that contain hornblende also contain relicts of or pseudomorphs after pyroxene. The amphibole commonly shows resorbed edges and sieve texture and is rimmed by opaque oxides. In pyrox. ene-bearing rocks, pyroxene grains have sharp edges and may show sieve texture. The plagioclase, which is also phenocrystic, is generally strongly zoned, Carlsbad-and albite-twinned, and locally shows glomeroporphyritic texture. Andesite samples commonly have two populations of plagioclase averaging $A n 35$ and $A n 60$ or a single plagioclase averaging about $A n 45-65$. In the two-plagioclase andesites, the more sodic plagioclase generally has resorbed edges. Plagioclase in basalt sam. ples usuarly has a composition of An $60-65$, whereas that in dacite samples lends to have a composition near

Table 1. Bulk chemistry and normative minerals of volcanic rocks, Meshik Formation. Sample locations shown on figure 1 .

\begin{tabular}{|c|c|c|c|c|c|c|c|c|c|c|c|}
\hline Field no. & $\begin{array}{c}77 \mathrm{AW} \\
102\end{array}$ & $\begin{array}{c}78 \mathrm{AWs} \\
18\end{array}$ & $\begin{array}{c}78 \mathrm{AW} \\
20\end{array}$ & $\begin{array}{c}78 \mathrm{AWs} \\
31\end{array}$ & $\begin{array}{c}\text { 78AWs- } \\
32\end{array}$ & $\begin{array}{c}78 \mathrm{AWs} \text {. } \\
58\end{array}$ & $\begin{array}{c}78 \mathrm{AWs}- \\
61\end{array}$ & $\begin{array}{c}78 \mathrm{AWS}- \\
98\end{array}$ & $\begin{array}{c}78 \mathrm{AWs} \\
111\end{array}$ & $\begin{array}{c}78 \mathrm{AWs} \\
134\end{array}$ & $\begin{array}{c}79 \mathrm{AW} \text { - } \\
2\end{array}$ \\
\hline Map no. & 5 & 11 & 12 & 15 & 16 & 19 & 20 & 21 & 22 & 23 & \\
\hline \multicolumn{12}{|c|}{ Bulk chemistry } \\
\hline $\mathrm{SiO}_{2}$ & 45.59 & 49,14 & 61.67 & 55.54 & 52.21 & 57.49 & 61.58 & 49.57 & 48.58 & 59.98 & 56.20 \\
\hline $\mathrm{Al}_{2} \mathrm{O}_{3}$ & 17.11 & 19.02 & 16.45 & 18.45 & 15.88 & 16.66 & 16.48 & 16.53 & 19.04 & 16.40 & 16.10 \\
\hline $\mathrm{Fe}_{2} \mathrm{O}_{3}$ & 4.97 & 5.62 & 4.87 & 3.43 & 2.90 & 4.26 & 4.03 & 2,64 & 4.51 & 2.88 & 3.38 \\
\hline $\mathrm{FeO}$ & 6.23 & 3.63 & 1.47 & 3.39 & 4.39 & 2.87 & 1.64 & 7.18 & 6.04 & 2.84 & 3.47 \\
\hline $\mathrm{MgO}$ & 6.49 & 4.75 & 2.21 & 4.34 & 7.84 & 3.30 & 1.96 & 5.65 & 4.68 & 3.57 & 5.85 \\
\hline $\mathrm{CaO}$ & 12.13 & 9.63 & 6.21 & 7.98 & 8.81 & 6.65 & 5.51 & 9.77 & 10.30 & 6.68 & 6.92 \\
\hline $\mathrm{Na}_{2} \mathrm{O}$ & 1.96 & 3.03 & 3.2 .1 & 3.23 & 2.64 & 2.98 & 3.31 & 2.41 & 2.68 & 3.52 & 3.32 \\
\hline $\mathrm{K}_{2} \mathrm{O}$ & 1.13 & 0.81 & 1.25 & 1.21 & 0.93 & 1.44 & 1.20 & 0.15 & 0.83 & 1.08 & 1.61 \\
\hline $\mathrm{TiO}_{2}$ & 1.03 & 0.74 & 0.69 & 0.75 & 0.69 & 0.80 & 0.59 & 1.46 & 1.02 & 0.77 & 0.97 \\
\hline $\mathrm{P}_{2} \mathrm{O}_{5}$ & 0.18 & 0.10 & 0.11 & 0.14 & 0.16 & 0.19 & 0.13 & 0.15 & 0.18 & 0.19 & 0.24 \\
\hline $\mathrm{MnO}$ & 0.18 & 0.20 & 0.09 & 0.13 & 0.14 & 0.08 & 0.07 & 0.15 & 0.23 & 0.11 & 0.12 \\
\hline $\mathrm{H}_{2} \mathrm{O}^{+}$ & 2.02 & 1.00 & 0.71 & 0.33 & 0.81 & 1.01 & 0.92 & 2.07 & 0.72 & 0.48 & 0.62 \\
\hline $\mathrm{H}_{2} \mathrm{O}^{-}$ & 1.21 & 2.65 & 1.62 & 0.61 & 1.20 & 1.87 & 2.07 & 0.41 & 1.42 & 1.20 & 1.00 \\
\hline $\mathrm{CO}_{2}$ & 0.16 & 0.13 & 0.27 & 0.05 & 1.10 & 0.80 & 0.21 & 1.23 & 0.08 & 0.06 & 0.11 \\
\hline Total & 100.39 & 100.35 & 100.33 & 99.58 & 99.64 & 99.85 & 99.60 & 99.36 & 100.31 & 99.76 & 9981 \\
\hline
\end{tabular}

\begin{tabular}{|c|c|c|c|c|c|c|c|c|c|c|c|}
\hline Quartz & $\cdots$ & 3.09 & 23.17 & 9.24 & 4.21 & 17.42 & 24.25 & 5.17 & 1.21 & 17.14 & 9.19 \\
\hline Corundum & $\cdots$ & $\cdots$ & $\cdots$ & $\ldots$ & $\cdots$ & $\cdots$ & 0.03 & $\ldots$ & $\ldots$ & $\cdots$ & $-\cdots$ \\
\hline Orthoclase & 6.88 & 4.96 & 7.56 & 7.15 & 5.69 & 8.80 & 7.36 & 0.93 & 5.00 & 6.51 & 9.10 \\
\hline Albite & 17.10 & 26.55 & 27.79 & 27.33 & 23.14 & 25.65 & 29.05 & 21.32 & 23.12 & 30.38 & 28.64 \\
\hline Anorthite & 35.62 & 37.18 & 27.41 & 32.37 & 29.77 & 29.02 & 27.47 & 35.38 & 38.20 & 26.28 & 25.05 \\
\hline $\begin{array}{l}\text { Diopside- } \\
\text { wollastonite } \\
\text { Diopside. }\end{array}$ & 10.52 & 4.68 & 1.43 & 2.67 & 6.02 & 1.60 & $\cdots$ & 5.96 & 5,30 & 2.62 & 3.49 \\
\hline $\begin{array}{l}\text { ferrosilite } \\
\text { Diopside. }\end{array}$ & 2.62 & 0.37 & $\cdots$ & 0.44 & 1.05 & 0.09 & $\cdots$ & 2.20 & 1.72 & 039 & $0 . \$ 1$ \\
\hline $\begin{array}{l}\text { enstatite } \\
\text { Hypersthene- }\end{array}$ & 7.10 & 8.72 & 1.22 & 1.98 & 4.40 & 1.31 & $\ldots$ & 9.48 & 3.27 & 1.96 & 2.70 \\
\hline fercosilite & 0.82 & 0.84 & $\ldots$ & 1.96 & 3.79 & 0.51 & $\cdots-$ & 7.10 & 4.51 & 1.41 & 1.84 \\
\hline $\begin{array}{l}\text { Hypersthene- } \\
\text { enstatite }\end{array}$ & 2.23 & 8.53 & 4.41 & 8.83 & 15.82 & 7.19 & 5.06 & 11.23 & 8.61 & 7.11 & 12.15 \\
\hline Olivine & 7.23 & $\cdots$ & $\cdots$ & $\cdots$ & $\cdots$ & $\cdots$ & $-\cdot-$ & $\ldots$ & $\ldots$ & $\ldots$ & $\cdots$ \\
\hline Magnetite & 7.43 & 8.44 & 3.10 & 4.97 & 4.36 & 6.39 & 3.61 & 4.00 & 6.67 & 4.26 & 5.00 \\
\hline Ilmenite & 2.02 & 1.46 & 1.34 & 1.36 & 1.42 & 1.57 & 1.16 & 2.88 & 1.97 & 1.49 & 1.88 \\
\hline Apstite & 0.43 & 0.24 & 0.26 & 0.32 & 0.38 & 0.46 & 0.31 & 0.36 & 0.42 & 0.45 & 0.57 \\
\hline Hematite & $\ldots$ & $\cdots$ & 2.33 & $\ldots$ & $\cdots$ & $\cdots$ & 1.69 & --- & $\ldots$ & $\cdots$ & $\cdots$ \\
\hline Total & $100.00^{\mathrm{a}}$ & $100.01^{\mathrm{a}}$ & $100.00^{\mathrm{a}}$ & 98.62 & $100.05^{\circ}$ & $100.01^{8}$ & $99.99^{a}$ & $100.01^{\mathrm{a}}$ & $100.00^{8}$ & $100.00^{2}$ & $100.02^{2}$ \\
\hline
\end{tabular}

Normative color index

$\begin{array}{lllllll}40.0 & 28.0 & 13.8 & 21.8 & 36.3 & 18.1 & 11.5\end{array}$

36.1

32.1

19.2

27.5

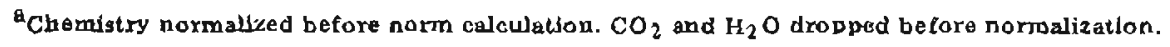


Table 2. Bulk chemistry and normative minerals of Eocene-Oligocene intrusive racks. Sample locations shown on fgure 1.

\begin{tabular}{|c|c|c|c|c|c|c|c|c|c|c|c|c|c|c|c|}
\hline Field no. & $\begin{array}{c}77 \mathrm{AWs}- \\
30 \\
1\end{array}$ & $\begin{array}{c}77 A W s- \\
40 \\
2\end{array}$ & $\begin{array}{c}77 \mathrm{AW}- \\
74 \\
4\end{array}$ & $\begin{array}{c}77 \mathrm{AWs}- \\
122 \\
6\end{array}$ & $\begin{array}{c}77 \mathrm{AWs}- \\
137\end{array}$ & $\begin{array}{c}77 \mathrm{AMs}- \\
1 \\
7\end{array}$ & $\begin{array}{c}78 \mathrm{AWs}- \\
5 \\
8\end{array}$ & $\begin{array}{c}78 \mathrm{AWs}- \\
11 \\
9\end{array}$ & $\begin{array}{c}78 A W s \\
17 \\
10\end{array}$ & $\begin{array}{c}78 \mathrm{AWs}- \\
24 \\
13\end{array}$ & $\begin{array}{c}78 \mathrm{AWs} \\
35 \\
17\end{array}$ & $\begin{array}{c}78 A \text { Ws } \\
42 \\
18\end{array}$ & $\begin{array}{c}79 \mathrm{ADt} \\
23 \\
25\end{array}$ & $\begin{array}{c}79 \mathrm{ADt} \\
95 \\
26\end{array}$ & $\begin{array}{c}\mathrm{R} 41358 \mathrm{~A} \\
28\end{array}$ \\
\hline \multicolumn{16}{|c|}{ Bulk chemistry } \\
\hline $\mathrm{SiO}_{2}$ & 59.17 & 50.02 & 59.80 & 64.74 & 66.60 & 55.54 & 54.47 & 63.46 & 47.14 & 54.11 & 62.79 & 58.19 & 58.60 & 57.10 & 62.03 \\
\hline $\mathrm{Al}_{2} \mathrm{O}_{3}$ & 17.64 & 18.15 & 15.40 & 16.18 & 16.12 & 17.56 & 16.02 & 15.60 & 17.11 & 17.47 & 16.40 & 17.53 & 16.10 & 15.50 & 15.18 \\
\hline $\mathrm{Fe}_{2} \mathrm{O}_{3}$ & 3.68 & 5.12 & 2.82 & 2.47 & 1.85 & 3.71 & 3.32 & 3.14 & 1.64 & 1.33 & 1.88 & 3.07 & 2.21 & 2.52 & 2.87 \\
\hline FeO & 2.32 & 6.18 & 1.76 & 2.12 & 2.36 & 5.00 & 5.50 & 1.82 & 7.01 & 4.72 & 3.12 & 3.08 & 3.67 & 4.01 & 3.09 \\
\hline $\mathrm{MgO}$ & 2.71 & 4.42 & 2.05 & 1.74 & 1.88 & 3.98 & 4.84 & 2.68 & 7.01 & 5.80 & 2.44 & 3.05 & 3.84 & 4.61 & 3.13 \\
\hline $\mathrm{CaO}$ & 6.54 & 8.07 & 5.46 & 4.37 & 4.04 & 8.28 & 7.53 & 4.45 & 8.74 & 6.84 & 5.37 & 5.16 & 5.91 & 6.66 & 5.44 \\
\hline $\mathrm{Na}_{2} \mathrm{O}$ & 3.69 & 2.75 & 2.47 & 3.93 & 3.73 & 3.10 & 3.20 & 3.68 & 3.22 & 5.08 & 3.37 & 4.50 & 3.53 & 2.71 & 3.08 \\
\hline $\mathrm{K}_{2} \mathrm{O}$ & 1.12 & 1.19 & 2.65 & 1.37 & 1.99 & 0.61 & 1.38 & 2.16 & 0.49 & 0.71 & 1.75 & 1.65 & 1.78 & 1.89 & 1.86 \\
\hline $\mathrm{TiO}_{2}$ & 0.52 & 0.83 & 0.53 & 0.53 & 0.65 & 0.95 & 1.04 & 0.71 & 0.96 & 0.87 & 0.55 & 0.75 & 0.63 & 0.79 & 0.60 \\
\hline $\mathrm{P}_{2} \mathrm{O}_{5}$ & 0.23 & 0.21 & 0.21 & 0.15 & 0.17 & 0.32 & 0.13 & 0.12 & 0.11 & 0.17 & 0.13 & 0.26 & 0.19 & 0.26 & 0.15 \\
\hline $\mathrm{MnO}$ & 0.13 & 0.21 & 0.09 & 0.08 & 0.03 & 0.17 & 0.16 & 0.06 & 0.55 & 0.11 & 0.13 & 0.10 & 0.14 & 0.16 & 0.06 \\
\hline $\mathrm{H}_{2} \mathrm{O}^{+}$ & 1.22 & 2.83 & 2.18 & 0.86 & 0.97 & 1.68 & 0.86 & 1.95 & 3.08 & 1.26 & 1.85 & 1.35 & 1.84 & 2.17 & 0.95 \\
\hline $\mathrm{H}_{2} \mathrm{O}^{-}$ & 0.60 & 0.56 & 0.98 & 0.13 & 0.11 & 0.16 & 0.72 & 0.53 & 0.29 & 0.21 & 0.38 & 0.12 & 0.43 & 0.05 & 0.30 \\
\hline $\mathrm{CO}_{2}$ & 0.69 & 0.34 & 3.51 & 0.08 & 0.05 & 0.17 & 0.24 & 0.05 & 2.09 & 0.20 & 0.23 & 0.05 & 0.78 & 1.26 & 0.19 \\
\hline Total & 100.26 & 100.88 & 99.91 & 98.75 & 100.55 & 101.23 & 99.47 & 100.41 & 99.44 & 98.88 & 100.39 & 98.86 & 99.65 & 99.69 & 98.93 \\
\hline \multicolumn{16}{|c|}{ Normative minerals } \\
\hline Quartz & 16.70 & 4.60 & 23.17 & 25.08 & 25.50 & 11.66 & 7.49 & 21.40 & $\cdots$ & $\ldots$ & 20.84 & 10.42 & 13.10 & 13.74 & 21.37 \\
\hline Corundum & $\ldots$ & $\ldots$ & $\ldots$ & 0.66 & 0.89 & $\cdots$ & $\cdots$ & $\ldots$ & $\cdots$ & $\cdots$ & $\cdots$ & $\cdots$ & $\cdots$ & $\cdots$ & $\cdots$ \\
\hline Orthoclase & 6.77 & 7.24 & 16.79 & 8.28 & 11.76 & 3.60 & 8.36 & 13.04 & 3.08 & 4.32 & 10.56 & 10.02 & 10.89 & 11.61 & 11.27 \\
\hline Albite & 31.94 & 23.95 & 22.41 & 34.01 & 31.56 & 26.23 & 27.74 & 31.81 & 28.97 & 44.22 & 29.12 & 39.12 & 30.92 & 23.83 & 26.73 \\
\hline Anorthite & 28.91 & 34.65 & 24.78 & 21.17 & 18.93 & 32.20 & 25.90 & 20.09 & 32.74 & 23.42 & 24.97 & 23.38 & 23.63 & 25.51 & 22.67 \\
\hline Diopside- & & & & & & & & & & & & & & & \\
\hline wollastonite & 1.15 & 2.15 & 1.17 & $\cdots$ & $\cdots$ & 2.84 & 4.81 & 0.69 & 5.26 & 4.32 & 0.57 & 0.49 & 2.27 & 2.95 & 1.67 \\
\hline Diopside- & & & & & & & & & & & & & & & \\
\hline ferrosilite & 0.08 & 0.73 & 0.04 & $\cdots$ & $\cdots$ & 0.88 & 1.49 & $\cdots$ & 1.92 & 1.23 & 0.20 & 0.10 & 0.64 & 0.74 & 0.36 \\
\hline $\begin{array}{l}\text { Diopside- } \\
\text { enstatite }\end{array}$ & 0.93 & 1.30 & 0.98 & --- & -- & 1.78 & 3.02 & 0.60 & 3.09 & 2.80 & 0.34 & 0.35 & 1.48 & 1.99 & 1.17 \\
\hline Hypersthene- & & & & & & & & & & & & & & & \\
\hline ferrosilite & 0.53 & 5.59 & 0.17 & 1.32 & 1.79 & 3.99 & 4.59 & -- & 2.46 & 3.38 & 3.39 & 2.03 & 3.64 & 3.70 & 2.13 \\
\hline $\begin{array}{l}\text { Hypersthene- } \\
\text { enstatite }\end{array}$ & 5.98 & 10.03 & 4.49 & 4.43 & 46 & 8.1 & 9.3 & 6. & 3.95 & 7.71 & 5.86 & 7.45 & 8.42 & 9.95 & 6.83 \\
\hline Olivine & $\cdots$ & Dento & 2.70 & $\ldots$ & $\cdots$ & $\ldots$ & $\ldots$ & 13.81 & 4.52 & $\ldots$ & -.- & -1.0 & $\begin{array}{l}0.42 \\
---\end{array}$ & - & .-- \\
\hline Magnetite & 5.46 & 7.64 & 4.39 & 3.66 & 2.68 & 5.38 & 4.93 & 4.09 & 2.53 & 1.98 & 2.78 & 4.57 & 3.32 & 3.80 & 4.27 \\
\hline Шmenite & 1.01 & 1.62 & 1.08 & 1.03 & 1.23 & 1.80 & 2.02 & 1.38 & 1.94 & 1.70 & 1.07 & 1.46 & 1.24 & 1.56 & I. 17 \\
\hline Apatite & 0.54 & 0.50 & 0.52 & 0.36 & 0.39 & 0.74 & 0.31 & 0.28 & 0.27 & 0.40 & 0.31 & 0.62 & 0.46 & 0.63 & 0.36 \\
\hline Hematite & $\ldots$ & $\ldots$ & $\ldots$ & .- & $\ldots$ & $\ldots$ & $\ldots$ & 0.39 & $\ldots$ & ... & ..- & --. & $\ldots$ & $\ldots$ & ... \\
\hline Total & $100,00^{\mathrm{a}}$ & $100.00^{\mathrm{a}}$ & $99.99^{\mathrm{a}}$ & $100.00^{\mathrm{a}}$ & 99.41 & 99.23 & $99.99^{a}$ & $99.99^{a}$ & $90.73^{a}$ & $95.48^{\mathrm{a}}$ & $100.01^{\mathrm{g}}$ & $100.01^{\mathrm{a}}$ & $100.01^{3}$ & $100.01^{\mathrm{a}}$ & $10000^{3}$ \\
\hline
\end{tabular}

$100.00^{\mathrm{a}} \quad 100.00^{\mathrm{a}} \quad 99.99^{\mathrm{a}} \quad 100.00^{\mathrm{a}} \quad 99.41 \quad 99.23$

$99.99^{\mathbf{a}} \quad 99.99^{\mathrm{a}}$

Normative color

index

$\begin{array}{lllllll}15.1 & 29.2 & 12.3 & 10.3 & 10.4 & 24.8 & 30.2\end{array}$

${ }^{\mathrm{a} C h e m i s t r y}$ normalized before norm calculation. $\mathrm{CO}_{2}$ and $\mathrm{H}_{2} \mathrm{O}$ dropped before normalization. 
An 40.45. (Plagioclase compositions were determined by using Carlsbad-albite (winning.) Partial alteration of the feldspars to sericite or clay minerals is almost ubiquitous. Calcite and epidote are common alteration products, and in some rocks the groundmass is chloritized. Apatite is a common (and oocasionally abundant) accessory. Quartz phenocrysts, generally with resorbed edges, sometimes occur in thin sections of andesite and basalt. A few thin sections---generally of basalt or leucobasalt--contain olivine. The groundmass of most Meshlk arc rocks is fine grained and composed of plagioclase feldspar and opaque minerals or devitrified glass. Textures range from glomeroporphyritic to subophitic. The disequilibrium mineral assemblages in some of these rocks, particularly the coexisting plagioclase compositions and the partially resorbed quartz phenocrysts, suggest mixing of magmas.

The rocks described above are typical of most flows and plugs in the Meshlk arc. Generally, the intrusive rocks (plugs) are characterized by hornblende and the extrusive rocks (flows) by pyroxene. Other common igneous rocks of the Meshik arc are agglomerate and breccia, including pyroclastic llows, nubble flows, and lahars; volcanic clasts are petrographically similar to the plugs and nows described above.

Figure 2 contains parts of AFM and normative quartz-orthoclase-plagioclase ternary diagrams for rocks of the Meshik arc; the lower diagram includes criterla used for the Streckeisen (1979) classification. The range and variability of chemical compositions of rocks of the Meshik are are virtually the same as those of late Tertiary igneous rocks from the central Alaska Peninsula (Wilson and others, 1981). The Meshik arc rocks lie in the calc-alkaline field of Ringwood (1977). An attempt to test the convergence direction by using $K_{2} 0$, $\mathrm{K}_{2} \mathrm{O} / \mathrm{SiO}_{2}$, or $\mathrm{K}_{2} \mathrm{O}$ in the limited ranges of $\mathrm{SiO}_{2}$ vs. distance from any supposed paleosubduction zone (Dickinson, 1968; Nielson and Stoiber, 1973) failed. There was no indication of increasing $\mathrm{K}_{2} \mathrm{O}$ with distance; all data groups either yielded random scatters of points or contained an insufficient number of points to yield meaningful plots, whether grouped by age, location, or chemical similarity.

In summary, the essential characteristics of the Meshik arc are:

1. Rocks of the arc include the Meshik Formation and related hypabyssal igneous and volcaniclastic rocks of the Stepovak Formation of the central Alaska Penin. sula.

2. Radiometric dating ( $\mathbf{K}-\mathrm{Ar}$ ) indicates that the arc was active between 48 and 22 m.y. B.P.; two-thirds of the age determinations on both intrusive and extrusive rocks fell between 40 and 30 m.y. B.P. Paleontologic evidence yields Eocene and Oligocene ages.

3. Volcanic and hypabyssal rocks range from basalt to dacite and many are deuterically or hydrothermally altered.
4. Sedimentary rocks are shale, siltstone, sandstone, and conglomerate, almost entirely composed of volcanic clasts and fragments.

\section{TECTONIC SIGNIFICANCE}

The Meshik arc and possible correlative igneous rocks in the Aleutian Islands (Marlow and others, 1973) and in the Alaska-Aleutian Range batholith (Reed and Lanphere, 1973) are evidence of subduction at a paleoAleutian trench during Eucene to Oligacene or earliest Miocene time. During middle and late Miocene time, the Bear Lake Formation (Burk, 1965) was deposited unconformably(?) on rocks of the Meshik arc; it has a large component of nonvolcanic clasts in the conglomeratlc phase. However, clasts that appear to be from the Meshik Formation are common, and the Bear Lake Formation probably represents reworking of a variety of earlier rocks. Overlying the Bear Lake Formation are volcanic and volcaniclastic rocks of the present-day Aleutian arc, including the Milky River Formation (Detterman and others, 1981). K-Ar age determinations suggest that this magmatic activity began in latest Miocene time and continued to the present (Wilson and others, 1981).

The range of radlometric dates on rocks of the Meshik arc provides good evidence for magmatic activity that lasted at least $15 \mathrm{~m} . \mathrm{y}$. and possibly $26 \mathrm{~m} . \mathrm{y}$. (assuming the minimum ages are realistlc); the activity was probably the result of subduction during Eocene, Oligocene, and earliest Miocene time. Radiometric dates of rocks from the Aleutian arc on the central Alaska Peninsula (Wilson and others, 1981; Wilson, 1982) also indicate at least $10 \mathrm{~m} . \mathrm{y}$. of subduction since late Miocene time.

Stone and Packer (1979) postulated large-scale migration of Baja Alaska (the Alaska Peninsula) on the basis of paleomagnetic measurements from Jurassic, Late Cretaceous, and Eocene sedimentary rocks. One speculation that can be made is that the lertane migrated when it was coupled to an oceanic plate (either the Kula or Pacific). Subduction under the terrane occurred when it was decoupled from the oceanic plate. If so, the Meshik arc and later Aleutian arc may indicate that most postulated migration between the Cretaceous and the present positions of the Alaska Perinsula occurred in Paleocene and middle Miocene time.

At some point during Tertiary lime, the Kula-Pacific Ridge or its remnants were subducted under the Alaska Peninsula and the Aleutian 1slands. DeLong and others $(1978 ; 1980)$ and Farrar and Dixon (1980) suggested that this subduction may have occurred about $35 \mathrm{~m} . \mathrm{y}$. B.P. or during early Oligocene time in the Aleutian Islands. The model of Delong and others $(1978,1980)$ predicts that subduction of the Kula-Pacific Ridge would cause a hiatus in activity in the subduction-related magmatic are. The Kula-Pacific Ridge (iig. 3) would migrate along the paleo-Aleutian trench at a (to p. 10) 


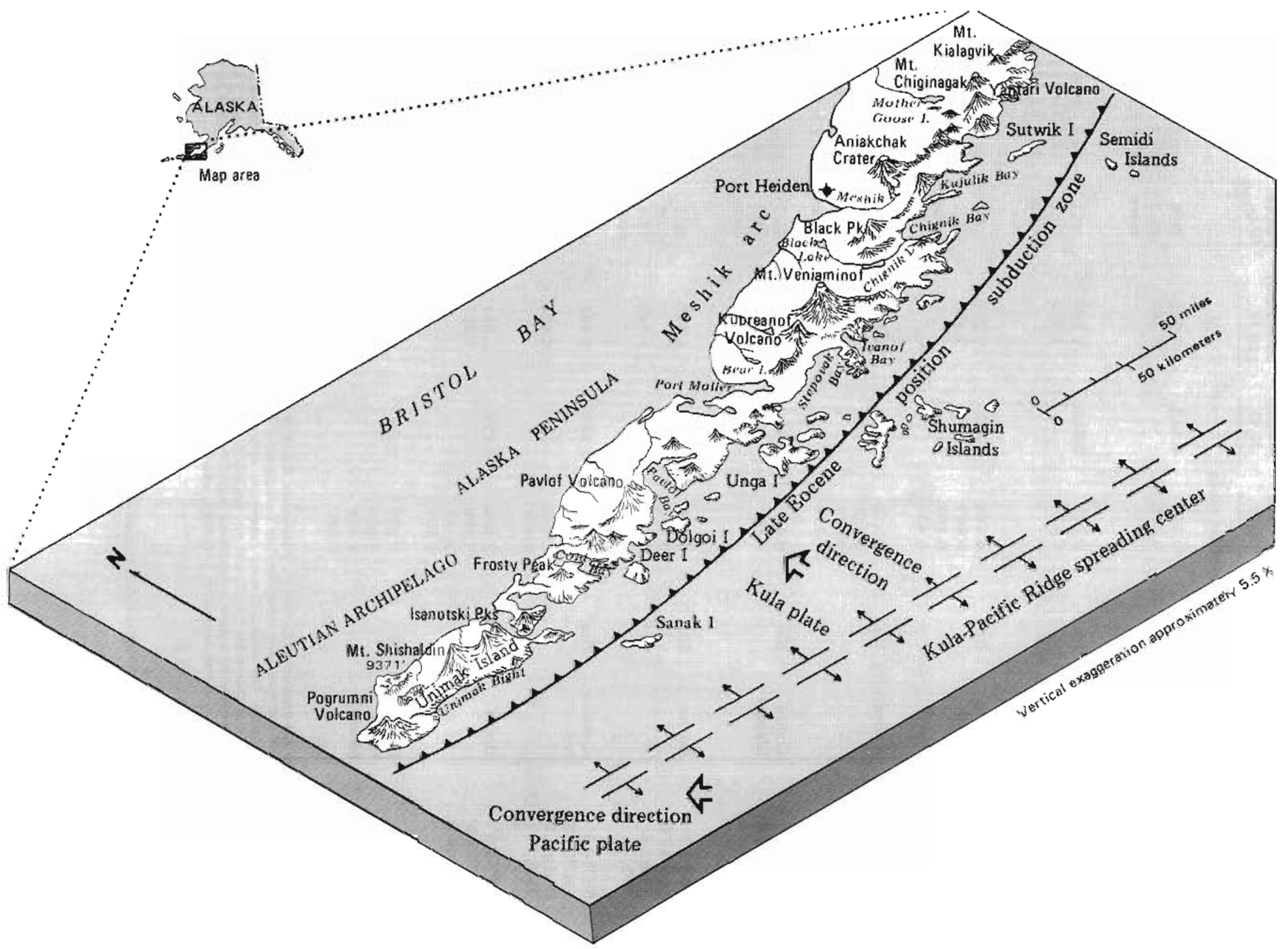


Table 3. Potassium-argon ages, Meshik arc. ${ }^{\mathrm{a}}$ b

\begin{tabular}{|c|c|c|c|c|c|c|c|c|}
\hline $\begin{array}{c}\text { Sample } \\
\text { (map no.) }\end{array}$ & $\begin{array}{c}\text { Lat-long } \\
\text { (quadrangle) }\end{array}$ & Rock type & $\begin{array}{l}\text { Mineral or } \\
\text { component } \\
\text { dated } \\
\end{array}$ & $\begin{array}{c}\text { Mean } \\
\text { percent } \\
\mathrm{K}_{2} \mathrm{O} \\
\end{array}$ & $\begin{array}{c}\text { Weight } \\
\text { percent } \\
\mathrm{K}_{2} \mathrm{O} \\
\end{array}$ & $\begin{array}{l}40^{\text {Ar rad }_{\text {Yad }}} \\
\text { (moles/gm) } \\
\times 10^{-11}\end{array}$ & $\begin{array}{l}\text { Percent } \\
40^{\text {Ar rad }}\end{array}$ & $\begin{array}{l}\text { Age } \pm 10 \\
\text { (m.y.) } \\
\end{array}$ \\
\hline \multicolumn{9}{|c|}{ Intrusive rocks } \\
\hline $\begin{array}{l}77 \mathrm{AMs} \cdot 1 \\
(7)\end{array}$ & $\begin{array}{l}58^{\circ} 13.5^{\prime} \mathrm{N} \\
158^{\circ} 28.6 \mathrm{~W} \\
\text { (Chignik } \\
\mathrm{A}-2 \text { ) }\end{array}$ & $\begin{array}{l}\text { Andesite } \\
\text { (dike) }\end{array}$ & Hb1 & $\begin{array}{l}0.944 \\
0.342\end{array}$ & 0.943 & $\begin{array}{l}1.301 \\
1.989\end{array}$ & $\begin{array}{l}29.6 \\
15.3 \\
\text { mean }\end{array}$ & $\begin{array}{l}26.2 \pm 0.57 \\
27.9 \pm 0.86 \\
27.1 \pm 1.58\end{array}$ \\
\hline $\begin{array}{l}77 \mathrm{AWs}-30 \\
\text { (1) }\end{array}$ & $\begin{array}{l}56^{\circ} 38.2^{\prime} \\
156^{\circ} 35.8^{\prime} \\
\text { (Sutwik Is. } \\
\text { C-5) }\end{array}$ & $\begin{array}{l}\text { Andesite } \\
\text { (dome) }\end{array}$ & $\mathrm{Hbl}$ & $\begin{array}{l}0.317 \\
0.321\end{array}$ & 0.819 & $\begin{array}{l}1.666 \\
1.700\end{array}$ & $\begin{array}{l}29.1 \\
35.2 \\
\text { mean }\end{array}$ & $\begin{array}{l}36.9 \pm 1.03 \\
36.7 \pm 0.79 \\
36.3 \pm 1.42\end{array}$ \\
\hline $\begin{array}{l}77 \mathrm{AWs}-40 \\
(2)\end{array}$ & $\begin{array}{l}56^{\circ} 38.2^{\prime} \\
157^{\circ} 28.9^{\prime} \\
\text { (Sutwik Is. } \\
\text { C-5) }\end{array}$ & $\begin{array}{l}\text { Leuco- } \\
\text { basalt }\end{array}$ & $\mathrm{Hbl}$ & $\begin{array}{l}0.466 \\
0.467 \\
0.468 \\
0.465\end{array}$ & 0.467 & $\begin{array}{l}2.287 \\
2.456\end{array}$ & $\begin{array}{l}24.2 \\
36.7 \\
\text { mean }\end{array}$ & $\begin{array}{l}33.7 \pm 0.60 \\
36.2 \pm 0.66 \\
35.0 \pm 1.95\end{array}$ \\
\hline $\begin{array}{l}77 \mathrm{AW}-46 \\
\text { (9) }\end{array}$ & $\begin{array}{l}56^{\circ} 38.2^{\prime} \\
157^{\circ} 27.7^{\prime} \\
\text { (Sutwik Is. } \\
\text { C-5) }\end{array}$ & Andesite(?) & Hb1 & $\begin{array}{l}0.310 \\
0.311 \\
0.311 \\
0.313\end{array}$ & 0.811 & $\begin{array}{l}1.712 \\
1.827\end{array}$ & $\begin{array}{l}19.8 \\
27.8 \\
\text { mean }\end{array}$ & $\begin{array}{l}37.81 \pm 1.58 \\
40.91 \pm 0.91 \\
39.1 \pm 1.80\end{array}$ \\
\hline $\begin{array}{l}77 \mathrm{AWs}-74 \\
(4)\end{array}$ & $\begin{array}{l}66^{\circ} 32.5^{\prime} \\
157^{\circ} 20.0^{\prime} \\
\text { (Sutwik Is. } \\
\text { C-4) }\end{array}$ & $\begin{array}{l}\text { Dacite } \\
\text { (dome) }\end{array}$ & Bio & $\begin{array}{l}8.46 \\
8.50\end{array}$ & 8.48 & $\begin{array}{l}43.81 \\
41.26\end{array}$ & $\begin{array}{l}43.7 \\
74.0 \\
\text { meası }\end{array}$ & $\begin{array}{l}35.5 \pm 0.64 \\
33.6 \pm 0.55 \\
34.5 \pm 1.60\end{array}$ \\
\hline $\begin{array}{l}77 \mathrm{AWs} \cdot 122^{\circ} \\
(6)\end{array}$ & $\begin{array}{l}56^{\circ} 11.7^{\prime} \\
158^{\circ} 19.0^{\prime} \\
\text { (Chignik } \\
\text { A.1) }\end{array}$ & Dacite & $\mathrm{Hb1}$ & $\begin{array}{l}0.338 \\
0.324 \\
0.332 \\
0.323\end{array}$ & 0.329 & $\begin{array}{l}1.125 \\
1.009\end{array}$ & $\begin{array}{l}24.1 \\
17.5 \\
\text { mean }\end{array}$ & $\begin{array}{l}23.57 \pm 0.59 \\
21.17 \pm 0.47 \\
22.4 \pm 1.86\end{array}$ \\
\hline $\begin{array}{l}78 \mathrm{AWs}-5^{d} \\
(8)\end{array}$ & $\begin{array}{l}56^{\circ} 56.5^{\prime} \\
156^{\circ} 57.0^{\prime} \\
\text { (Sutwik Is. } \\
\text { D-8) }\end{array}$ & $\begin{array}{l}\text { Andesite } \\
\text { (sill) }\end{array}$ & Plage & $\begin{array}{l}0.483 \\
0.485 \\
0.482 \\
0.481\end{array}$ & 0.483 & $\begin{array}{l}3.402 \\
3.354\end{array}$ & $\begin{array}{l}45.5 \\
40.4 \\
\text { mean }\end{array}$ & $\begin{array}{l}48.55 \pm 0.55 \\
47.64 \pm 0.29 \\
48.1 \pm 0.89\end{array}$ \\
\hline $\begin{array}{l}78 A W s-11^{f} \\
(9)\end{array}$ & $\begin{array}{l}56^{\circ} 59.0^{\prime} \\
157^{\circ} 07.5^{\prime} \\
\text { (Sutwik Is } \\
\text { D-4) }\end{array}$ & Dacite & $\mathrm{HbI}$ & $\begin{array}{l}0.495 \\
0.492 \\
0.487 \\
0.492\end{array}$ & 0.492 & $\begin{array}{l}1.381 \\
1.357\end{array}$ & $\begin{array}{l}30.5 \\
31.0 \\
\text { mean }\end{array}$ & $\begin{array}{l}19.42 \pm 0.16 \\
19.08 \pm 0.16 \\
19.3 \pm 0.33\end{array}$ \\
\hline $\begin{array}{l}\text { 78AWs-17 } \\
(10)\end{array}$ & $\begin{array}{l}56^{\circ} 38.7^{\prime} \\
167^{\circ} 25.0^{\prime} \\
\text { (Sutwik Is. } \\
\text { C-5) }\end{array}$ & $\begin{array}{l}\text { Leuco- } \\
\text { basalt } \\
\text { (dome) }\end{array}$ & $\mathrm{Hb} 1$ & $\begin{array}{l}0.397 \\
0.405 \\
0.405 \\
0.995\end{array}$ & 0.401 & $\begin{array}{l}1.911 \\
2.068\end{array}$ & $\begin{array}{l}33.3 \\
36.2 \\
\text { mean }\end{array}$ & $\begin{array}{l}32.84 \pm 0.48 \\
35.52 \pm 0.51 \\
34.2 \pm 2.02\end{array}$ \\
\hline
\end{tabular}

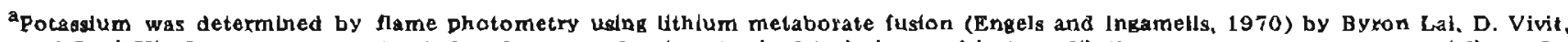
and Paul Klock. Argon was extracted and measured using standard lechniques of isotope-dulution mass spectromeery. especially as desexibed by Dalrymple and Lasphere (1969). The analytical error asgigned to each age is an egtimate of the standard deviatlon of analytical precision using the mathod of Cox and Dalrymple (1967) and my calculated estimates of uncertainties in the concentration of 38 Ar tracer and potassium measurements. 1 performed sample preparation, argon exirgction, and oata reductjon with assistanco from Nora Show, Rita Taylor, Brian Ho, and L.B. Gray, except for sample R-41358A, which was analyzed by M.L. Sillerman.

${ }^{b}$ Constants used: $\lambda=0.72 \times 10^{-1} 1_{y r^{-1}}$$$
\begin{array}{ll}
\lambda_{E} & =5.72 \times 10^{-1} \mathrm{yr}^{-1} \\
\lambda_{E} & =8.78 \times 10^{-11} \mathrm{yr}^{-1} \\
\lambda \hat{\beta} & =4.863 \times 10^{-1} \mathrm{yr}^{-1} \\
40_{\mathrm{K} / \mathrm{K}} & =1.167 \times 10^{-4} \mathrm{~mol} / \mathrm{mol}
\end{array}
$$

cMinimum age, possibly reset due to proximity to Devils batholith. Impure hornblende concentrate with inclusions of plagioclase.

Are may be too old, possibly due to exoess armon.

Ehole rock and plagioclase are HF treated (Wilson, 1980).

Minimum age, passibly reset due to nearby Quaternary volcaniam. 
Table 9. (con.)

\begin{tabular}{|c|c|c|c|c|c|c|c|c|}
\hline $\begin{array}{c}\text { Sample } \\
\text { (map no.) }\end{array}$ & $\begin{array}{c}\text { Lat-long } \\
\text { (quadrangle) } \\
\end{array}$ & Rock type & $\begin{array}{l}\text { Mineral or } \\
\text { component } \\
\text { dated }\end{array}$ & $\begin{array}{c}\text { Mean } \\
\text { percent } \\
\mathrm{K}_{2} \mathrm{O} \\
\end{array}$ & $\begin{array}{c}\text { Weight } \\
\text { percent } \\
\mathrm{K}_{2} \mathrm{O}\end{array}$ & $\begin{array}{l}\frac{40 \mathrm{Ar}_{\mathrm{rad}}}{(\mathrm{moles} / \mathrm{gm})} \\
\times 10^{-11}\end{array}$ & $\begin{array}{l}\text { Percent } \\
40 \text { Ar } r a d\end{array}$ & $\begin{array}{c}\text { Age } \pm 1 \sigma \\
\text { (m.y.) }\end{array}$ \\
\hline $\begin{array}{c}78 \mathrm{AWS}-24 \\
(18)\end{array}$ & $\begin{array}{l}56^{\circ} 47.3^{\prime} \\
167^{\circ} 11.8^{\prime} \\
\text { (Sutwik Is. } \\
\text { D-4) }\end{array}$ & $\begin{array}{l}\text { Andesite } \\
\text { (sill) }\end{array}$ & $\mathrm{Hb} 1$ & $\begin{array}{l}0.430 \\
0.428 \\
0.431 \\
0.430\end{array}$ & 0.430 & $\begin{array}{l}2.161 \\
2.020\end{array}$ & $\begin{array}{l}30.9 \\
35.2 \\
\text { mean }\end{array}$ & $\begin{array}{l}34.59 \pm 0.55 \\
32.36 \pm 1.65 \\
33.5 \pm 1.69\end{array}$ \\
\hline $\begin{array}{c}78 \mathrm{AWs} \cdot 27 \\
(14)\end{array}$ & $\begin{array}{l}56^{\circ} 47.9^{\prime} \\
157^{\circ} 13.7^{\prime} \\
\text { (Sutwik Is. } \\
\text { D.4) }\end{array}$ & $\begin{array}{l}\text { Aulolith } \\
\text { in dacite(?) } \\
\text { dome }\end{array}$ & Hb1 & $\begin{array}{l}0.391 \\
0.394 \\
0.391 \\
0.387\end{array}$ & 0.391 & $\begin{array}{l}2.150 \\
2.019\end{array}$ & $\begin{array}{l}32.9 \\
27.7 \\
\text { mean }\end{array}$ & $\begin{array}{l}37.8 \pm 0.32 \\
35.5 \pm 0.31 \\
36.7 \pm 1.67\end{array}$ \\
\hline $\begin{array}{c}78 A W 5-35 \\
(17)\end{array}$ & $\begin{array}{l}56^{\circ} 49.1^{\prime} \\
157^{\circ} 56.3 \\
\text { (Sutwik Is. } \\
\text { D-6) }\end{array}$ & $\begin{array}{l}\text { Dacite } \\
\text { (dome) }\end{array}$ & $\mathrm{Hb} 1$ & $\begin{array}{l}0.366 \\
0.364 \\
0.365 \\
0.366\end{array}$ & 0.365 & $\begin{array}{l}1.800 \\
1.858\end{array}$ & $\begin{array}{l}36.0 \\
18.9 \\
\text { mean }\end{array}$ & $\begin{array}{l}33.93 \pm 0.16 \\
35.01 \pm 0.38 \\
34.5 \pm 0.85\end{array}$ \\
\hline $\begin{array}{c}78 \mathrm{AWs} \cdot 42 \\
(18)\end{array}$ & $\begin{array}{l}56^{\circ} 30.4^{\prime} \\
157^{\circ} 42.1^{\prime} \\
\text { (Sutwik Is. } \\
\text { C-6) }\end{array}$ & Andesile & Hb1 & $\begin{array}{l}0.662 \\
0.663 \\
0.663 \\
0.661\end{array}$ & 0.662 & $\begin{array}{l}3.182 \\
3.123\end{array}$ & $\begin{array}{l}48.7 \\
46.6 \\
\text { mean }\end{array}$ & $\begin{array}{l}33.08 \pm 0.14 \\
32.46 \pm 0.14 \\
32.8 \pm 0.48\end{array}$ \\
\hline $\begin{array}{l}\text { 79ADL-23 } \\
(25)\end{array}$ & $\begin{array}{l}57^{\circ} 12.1^{\prime} \\
156^{\circ} 58.8^{\prime} \\
\text { (Ugashik } \\
\text { A-3) }\end{array}$ & $\begin{array}{l}\text { Allered } \\
\text { andesite }\end{array}$ & Hbl 1 & $\begin{array}{l}0.502 \\
0.503 \\
0.504 \\
0.504\end{array}$ & 0.503 & $\begin{array}{l}2.475 \\
2.563\end{array}$ & $\begin{array}{l}44.1 \\
36.1 \\
\text { mean }\end{array}$ & $\begin{array}{l}33.9 \pm 0.17 \\
35.0 \pm 0.16 \\
34.5 \pm 0.87\end{array}$ \\
\hline $\begin{array}{l}79 A D t \cdot 95 \\
(26)\end{array}$ & $\begin{array}{l}57^{\circ} 14.8^{\prime} \\
156^{\circ} 54.6^{\prime} \\
\text { (Ugashik } \\
\text { A-3) }\end{array}$ & Andesite & Hb1 & $\begin{array}{l}0.732 \\
0.738 \\
0.725 \\
0.732\end{array}$ & 0.732 & $\begin{array}{l}3.670 \\
3.811\end{array}$ & $\begin{array}{l}48.6 \\
44.1 \\
\text { mean }\end{array}$ & $\begin{array}{l}34.5 \pm 0.29 \\
35.8 \pm 0.29 \\
35.2 \pm 1.01\end{array}$ \\
\hline $\begin{array}{c}\mathrm{R} 41958 \cdot \mathrm{A} \\
(28)\end{array}$ & $\begin{array}{l}57^{\circ} 14.2^{\prime} \\
157^{\circ} 03.0^{\prime} \\
\left(U^{\prime} g a s h i k\right. \\
\Lambda-4)\end{array}$ & Dacite & Hb1 & $\begin{array}{l}1.056 \\
1.050 \\
1.087\end{array}$ & 1.048 & $\begin{array}{l}\text { 5. } 298 \\
5.367\end{array}$ & $\begin{array}{l}52.0 \\
57.0 \\
\text { mean }\end{array}$ & $\begin{array}{l}34.8 \pm 0.45 \\
35.2 \pm 0.45 \\
35.0 \pm 0.70\end{array}$ \\
\hline Do. & Do. & Do. & Bio & $\begin{array}{l}8.67 \\
8.77 \\
8.67\end{array}$ & 8.70 & 39.67 & 77.0 & $31.4 \pm 0.90$ \\
\hline & & & Vol & canic rocks & & & & \\
\hline $\begin{array}{c}77 \mathrm{AW}-102 \\
\text { (5) }\end{array}$ & $\begin{array}{l}55^{\circ} 57.0^{\prime} \\
169^{\circ} 21.0^{\prime} \\
\text { (Stepovak } \\
\text { Bay D-5) }\end{array}$ & $\begin{array}{l}\text { Leuco- } \\
\text { basalt }\end{array}$ & $W R^{e}$ & $\begin{array}{l}1.136 \\
1.085 \\
1.100 \\
1.089\end{array}$ & 1.103 & $\begin{array}{l}6.583 \\
6.363\end{array}$ & $\begin{array}{l}83.3 \\
79.1 \\
\text { mean }\end{array}$ & $\begin{array}{l}41.01 \pm 0.88 \\
39.65 \pm 0.85 \\
40.3 \pm 1.56\end{array}$ \\
\hline $\begin{array}{c}78 \mathrm{AWs}-18 \\
(11)\end{array}$ & $\begin{array}{l}56^{\circ} 37.5^{\prime} \\
157^{\circ} 34.5^{\prime} \\
\text { (Sutwik Is. } \\
\text { C.5) }\end{array}$ & $\begin{array}{l}\text { Leuco- } \\
\text { basalt }\end{array}$ & WR & $\begin{array}{l}0.765 \\
0.786 \\
0.790 \\
0.767\end{array}$ & 0.777 & $\begin{array}{l}4.171 \\
4.252\end{array}$ & $\begin{array}{l}60.7 \\
69.2 \\
\text { mean }\end{array}$ & $\begin{array}{l}36.91 \pm 0.69 \\
37.62 \pm 0.64 \\
37.3 \pm 1.03\end{array}$ \\
\hline $\begin{array}{l}78 \mathrm{AWs} \cdot 20 \\
(12)\end{array}$ & $\begin{array}{l}56^{\circ} 43.0^{\prime} \\
157^{\circ} 49.5^{\prime} \\
\text { (Sutwik ls. } \\
\text { C-6) }\end{array}$ & Dacite & WR & $\begin{array}{l}1.395 \\
1.374 \\
1.374 \\
1.368\end{array}$ & 1.378 & $\begin{array}{l}7.080 \\
7.562\end{array}$ & $\begin{array}{l}84.8 \\
72.6 \\
\text { mean }\end{array}$ & $\begin{array}{l}35.40 \pm 0.34 \\
37.73 \pm 0.40 \\
36.6 \pm 1.78\end{array}$ \\
\hline
\end{tabular}


Table 3. (con.)

\begin{tabular}{|c|c|c|c|c|c|c|c|c|}
\hline $\begin{array}{c}\text { Sample } \\
\text { (map no.) } \\
\end{array}$ & $\begin{array}{c}\text { Lat-long } \\
\text { (quadrangle) }\end{array}$ & Rock type & $\begin{array}{l}\text { Mineral or } \\
\text { component } \\
\text { dated } \\
\end{array}$ & $\begin{array}{c}\text { Mean } \\
\text { percent } \\
\mathrm{K}_{2} \mathrm{O} \\
\end{array}$ & $\begin{array}{c}\text { Weight } \\
\text { percent } \\
\mathrm{K}_{2} \mathrm{O} \\
\end{array}$ & $\begin{array}{l}\frac{40 \text { Ar rad }}{(\mathrm{moles} / \mathrm{gm})} \\
\times 10^{-11}\end{array}$ & $\begin{array}{l}\text { Percent } \\
40 \text { Arrad }\end{array}$ & $\begin{array}{c}\operatorname{Age} \pm 10 \\
\left(\mathrm{~m} . y_{2}\right) \\
\end{array}$ \\
\hline $\begin{array}{c}78 \mathrm{AWs} \cdot 31 \\
(15)\end{array}$ & $\begin{array}{l}56^{\circ} 33.0^{\prime} \\
156^{\circ} 59.6^{\prime} \\
\text { (Sutwik Is. } \\
\text { C.4) }\end{array}$ & Andesite & WR & $\begin{array}{l}1.258 \\
1.265 \\
1.261 \\
1.257\end{array}$ & 1.260 & $\begin{array}{l}6.553 \\
6.505\end{array}$ & $\begin{array}{l}90.5 \\
84.9 \\
\text { mean }\end{array}$ & $\begin{array}{l}30.35 \pm 0.47 \\
30.10 \pm 0.14 \\
30.2 \pm 0.49\end{array}$ \\
\hline $\begin{array}{c}78 \mathrm{AWs} \cdot 32 \\
(16)\end{array}$ & $\begin{array}{l}56^{\circ} 31.6^{\prime} \\
157^{\circ} 11.7^{\prime} \\
\text { (Sulwik Is. } \\
\text { C.4) }\end{array}$ & Andesite & WR & $\begin{array}{l}0.981 \\
0.983 \\
0.985 \\
0.983\end{array}$ & 0.983 & $\begin{array}{l}4.432 \\
4.332\end{array}$ & $\begin{array}{l}67.1 \\
72.2 \\
\text { mean }\end{array}$ & $\begin{array}{l}31.05 \pm 0.48 \\
30.36 \pm 0.13 \\
30.7 \pm 0.70\end{array}$ \\
\hline $\begin{array}{c}78 \mathrm{AWs} \cdot 58 \\
(19)\end{array}$ & $\begin{array}{l}56^{\circ} 30.4^{\prime} \\
157^{\circ} 49.4^{\prime} \\
\text { (Sutwik Is } \\
\text { C.6) }\end{array}$ & Dacite & WR & $\begin{array}{l}1.554 \\
1.557 \\
1.530 \\
1.530\end{array}$ & 1543 & $\begin{array}{l}7.694 \\
7.748\end{array}$ & $\begin{array}{l}90.6 \\
89.8 \\
\text { mean }\end{array}$ & $\begin{array}{l}34.32 \pm 0.61 \\
34.56 \pm 0.36 \\
\mathbf{3 4 . 4} \pm 0.73\end{array}$ \\
\hline $\begin{array}{c}78 \mathrm{AWs}-61 \\
(20)\end{array}$ & $\begin{array}{l}56^{\circ} 36.1^{\prime} \\
157^{\circ} 58.9^{\prime} \\
\text { (Sutwik Is. } \\
\text { C-6) }\end{array}$ & Dacite & WR & $\begin{array}{l}1.210 \\
1.213 \\
1.206\end{array}$ & 1.210 & $\begin{array}{l}6.107 \\
5.985\end{array}$ & $\begin{array}{l}94.8 \\
86.4 \\
\text { mean }\end{array}$ & $\begin{array}{l}34.74 \pm 0.16 \\
34.05 \pm 0.16 \\
34.4 \pm 0.54\end{array}$ \\
\hline $\begin{array}{l}78 \wedge W_{s-98} \\
(21)\end{array}$ & $\begin{array}{l}56^{\circ} 12.7^{\prime} \\
158^{\circ} 19.9^{\prime} \\
\text { (Chignik } \\
\text { A-2) }\end{array}$ & $\begin{array}{l}\text { Leuco. } \\
\text { basalt }\end{array}$ & WR & $\begin{array}{l}0.201 \\
0.200 \\
0.199 \\
0.203\end{array}$ & 0.201 & $\begin{array}{l}6.486 \\
5.826\end{array}$ & $\begin{array}{l}20.4 \\
25.8 \\
\text { mean }\end{array}$ & $\begin{array}{l}22.31 \pm 0.33 \\
20.05 \pm 0.38 \\
21.2 \pm 1.68\end{array}$ \\
\hline $\begin{array}{l}\text { 78AWs-111 } \\
(22)\end{array}$ & $\begin{array}{l}56^{\circ} 01.4^{\prime} \\
159^{\circ} 20.2^{\prime} \\
\text { (Chignik } \\
\text { A.5) }\end{array}$ & $\begin{array}{l}\text { Leuco- } \\
\text { basalt }\end{array}$ & WR & $\begin{array}{l}0.957 \\
0.987 \\
0.974 \\
0.957\end{array}$ & 0.971 & $\begin{array}{l}5.615 \\
5449\end{array}$ & $\begin{array}{l}65.9 \\
78.8 \\
\text { mean }\end{array}$ & $\begin{array}{l}39.72 \pm 0.79 \\
38.56 \pm 0.77 \\
39.1 \pm 1.37\end{array}$ \\
\hline $\begin{array}{c}78 \mathrm{AWs}-134 \\
(23)\end{array}$ & $\begin{array}{l}56^{\circ} 17.1^{\prime} \\
168^{\circ} 35.2^{\prime} \\
\text { (Chignik } \\
\text { B-2) }\end{array}$ & Dacite & WR & $\begin{array}{l}1.093 \\
1.134 \\
1.132 \\
1.106\end{array}$ & 1.116 & $\begin{array}{l}4.296 \\
4.195\end{array}$ & $\begin{array}{l}57.3 \\
66.6 \\
\text { mean }\end{array}$ & $\begin{array}{l}26.54 \pm 0.56 \\
25.92 \pm 0.51 \\
26.2 \pm 0.87\end{array}$ \\
\hline $\begin{array}{c}79 A W_{s} \cdot 2 \\
(24)\end{array}$ & $\begin{array}{l}67^{\circ} 06.6^{\prime} \\
157^{\circ} 38.2^{\prime} \\
\text { (Ugashik } \\
\text { A-5) }\end{array}$ & Andesite & WR & $\begin{array}{l}1.564 \\
1.547 \\
1.534 \\
1.543\end{array}$ & 1.547 & $\begin{array}{l}6.249 \\
6.291\end{array}$ & $\begin{array}{l}80.0 \\
79.0 \\
\text { mean }\end{array}$ & $\begin{array}{l}27.85 \pm 0.25 \\
28.03 \pm 0.25 \\
27.94 \pm 0.38\end{array}$ \\
\hline $\begin{array}{c}79 \mathrm{ACe} \cdot 20 \\
(27)\end{array}$ & $\begin{array}{l}57^{\circ} 05.9^{\prime} \\
157^{\circ} 48.1^{\prime} \\
\text { (Ugashik } \\
\text { A.6) }\end{array}$ & Basalt & WR & $\begin{array}{l}0.563 \\
0.565 \\
0.561\end{array}$ & 0.563 & $\begin{array}{l}2.007 \\
2.060\end{array}$ & $\begin{array}{l}52.5 \\
40.0 \\
\text { mean }\end{array}$ & $\begin{array}{l}24.6 \pm 0.15 \\
25.2 \pm 0.13 \\
24.9 \pm 0.49\end{array}$ \\
\hline
\end{tabular}

rate dependent on ridge orientation, the rate of convergence between the ridge and overriding plate, and segmentation of the ridge to arrive at a paleo-Aleutian trench of the central Alaska Peninsula. About 5 to $10 \mathrm{~m} . \mathrm{y}$. is necessary for arrival of the Kula-Pacific Ridge at the paleo-Aleutian trench off the central Alaska Peninsula assuming that:
1. The Kula-Pacific Ridge was oriented approximately east-west.

2. Orientation of the Aleutian Islands-Alaska Peninsula block was about the same during Oligocene and Miocene time as at present. This results in a convergence distance of approximately 3 degrees of latitude.

3. The Kula plate and the plate that included the central Alaska Peninsula (North American plate?) were oriented approximately morth-south and converged at a 
Tabie 4. Descriplions of daled and analyzed rochs. Map numbers shown on figure 1.

Map

no.

$177 \mathrm{AWs}-30$, andesite, Cape Kumlik. Light.greenish-gray, porphyritic andesite with hornblende phenocrysts and strongly zoned glomeroporphyritic plagioclase phenocrysts (about $\mathrm{An}_{5}$, allhough some phenocrysts are $A n_{30}$ ). Pyroxene peeudomorphs of calcite with chlorite or talc. Abundant accessory manganese-bearing purple apatite. Groundmass with abundant opaque oxides and possibly devitrified glass. Thoroughly fractured, probably protoclastic texture.

$277 \mathrm{AWs}-10$, leucobasalt, Cape Kumlik. Dark-green, porphyritic leucobasalt with hornblende phenocrysts up to 10 $\mathrm{mm}$ diam. Altered plagioclase phenocrysts ( $\mathrm{A} \mathrm{n}_{>} \mathrm{so}$ ). Abundant calcite, chlorite, and epidote. Hornblende phenocrysts partially altered to chlorite. Phenocrysts and groundmass fractured; may be cataclastic rather than protoclastic. Dike in mineralized area.

$377 \mathrm{AW}-46$, andesite(?), Cape Kumlik. Dark-green, porphyritic andesite(?) with chloritized amphibole phenocrysts and alcered, zoned plagioclase phenocrysts $\left(A n_{35}\right.$ and $\left.A n_{55}\right)$. Minor quartz. Rock is deuterically altered; calcite is common. In mineralized area.

$477 \mathrm{AW} \cdot 74$, dacite, Sutwik Island. Relatively fresh biotite phenocrysts(?) in thoroughly altered, tan dacike. Hornblende phenocrysts altered to opaque oxides and calcite; sericitized plagioclase of indeterminate composition; quartz and abundant accessory apatite and sphene.

577 AWs-102, leucobasalt, Ivanof River, Slepovak Bay Quadrangle. Dark gray, fine-grained leucobasalt flow with laths of plagioclase $\left(A n_{5}-60\right)$ and phenocrysts of clinopyroxene in groundmass of interstitial glass. Hyalophitic texture.

$677 \mathrm{AWs}-122$, ducile, Castle Bay. Light-gray, iron-stained dacile with hornblende and plagioclase phenocrysts (A $n_{30}$ ?) in fine-grained groundmass. Some quartz, hydrothermal(?) biotite, and sericite. Hornblende is sparsely distributed in long laths. Hyalophitic lexlure.

777 AMs-1, andesile, Mallard Duck Bay. Propylitically altered hornblende-andesite dike that intrudes volcanic pile of Mallard Duck Bay prospect. Plagioclase and hornblende phenocrysts in fine-grained groundmass of devitrified glass. Disseminated hydrothermal chlorite and epidote are abundant.

$878 \mathrm{AWs}-5$, andesite, Nakalilok Bay. Gray, [ine- to medium-grained andesite. Orthopyroxene and clinopyroxene with unaltered plagioclase phenocrysts $\left(\mathrm{An}_{4} 5\right)$. Minor groundmass of opaque oxides, fine-grained plagioclase, and iddingsite(?). Some calcite. Intersertal porphyritic texture.

$978 \mathrm{AWs}-11$, dacite, north edge, Sutwik Island Quadrangle. Gray, poruhyritic dacite with phenocrysts of green hornblende and plagioclase. Strongly zoned and Carlsbad-twinned plagioclase phenocrysts are of indeterminate composition due to sericitic alteration. Cataclastic porphyritic texture; phenocrysis shattered and dislocated. Miarolitic(?) cavities Eilled with rusty quartz crystals.

$1078 \mathrm{AWs}-17$, leucobasalt, Kumlik Island. Green, porphyritic leucobasalt. Large phenocrysts of hornblende ( $>1 \mathrm{~cm}$ ) and augite. Unevenly distributed xenoliths rich in homblende and plagioclase. Minor plagioclase phenocrysts $\left(A n_{60}\right)$ are sericitically altered. Abundant calcite, chlorite, and sericite in fine.grained groundmass.

11 78AWs-18, leucobasalt, Cape Kumlik. Dark-gkeen, porphyritic leucobasalt. Plagioclase (Anss) phenocrysts and minor pyroxene in groundmass largely composed of glass and devitrified glass. Hyalopilitic texture. Very minor iddingsite(?). Dike intrudes sediments of Tolstoi Formation.

$1278 \mathrm{AWs} \cdot 20$, dacite, North fork, Kujulik Bay. Green gray hormblende-dacite sill or plug in Meshik Formation. Hornblende and plagioclase $\left(A B_{5}\right)$ phenocrysts in groundmass of glass. Plagioclase is glomeroporphyritic.

$1378 \mathrm{AWs} \cdot 24$, andesite, Cape Kunmik. Light-gray, porphyritic hormblende andesite. Green, pleochroic hornblende phenocrysts in groundmass of hornblende and sericitically altered plagioclase. Sphene and actinolite alteration products from pyroxene. Weakly developed flow structure. Sample collected from rubble mixed with hornfels apparently along upper contact of intrusion.

$1478 \mathrm{AWs} \cdot 27$, autolith, Cape Kunmik. Coarse-grained, dark-brown-black autolith composed of pyroxene and hornblende collocted from dacite(?) dome. Plagioclase in sill is strongly zoned with An 60 cores. Autolith almost entirely composed of pyroxene and hornblende with very minor interstitial plagioclase. Pyroxene was originally subcalcic augite, but is now exsolving orthopyroxene and hornblende. Heleradcumulate texture. 
$1578 \mathrm{AWs}-31$, andesite, Foggy Cape. Dark-gray, porphyritic andesite with plagioclase phenocrysts (Anss) and phenocrysts of orthopyroxene and clinopyroxene. Groundmass of very fine grained plagioclase and pyroxene. Weak development of flow structure. Very minor alteration of plagioclase.

$1678 \mathrm{AWs} \cdot 32$, andesite, Sutwik Island. Dark-gray andesite with phenocrysts of plagioclase $\left(\mathrm{An}_{55-60}\right)$ and minor clinopyroxene. Serrate texture with medium to very fine grained crystals. Orthopyroxene phenocrysts apparent. ly altered to bastite. Weak development of flow structure. Feldspar unaltered.

$1778 \mathrm{AWs} \cdot 35$, dacite. Pinnacle Mountain. Light gray dacite with phenocrysts of green, pleochroic hornblende and plagioclase $\left(A n_{60}\right)$. Rare quattz phenocrysts(?) partially resorbed. Very fine grained groundmass, primarily of feldspar. Most plagioclase phenocrysts are broken and dislocazed; general alignment of hornblende phenocrysts indicates weak development of flow structure.

$1878 \mathrm{AWs}-42$, andesite, Unavikshak Island. Gray, porphyrilic andesice with phenocrysts of plagioclase (Anss), hornblende, and opaque oxides. Phenocrysts range from $4 \mathrm{~mm}$ lo near groundmass and all show resorption. Plagioclase zoned; alteration varies with zoning. Hyalophitıc, porphyritic texture.

$1978 \mathrm{AWs} \cdot 58$, dacite, VABM Easy, Gray-brown, porphyritic dacile wilh hornblende and plagioclase $\left(\mathrm{An}_{5} 5\right)$ phenocrysts. Groundmass of fine.grained plagioclase, glass, and opaque oxides. Pilotaxitic texture.

$2078 \mathrm{AW} \cdot 61$, dacite, VABM Julik. Gray green, porphyritic dacile Phenocrysts of hornblende and plagioclase (Ans 5 ?) in extremely line grained groundmass of plagioclase(?) and glass. Hornblende phenocrysts oullined in opaque oxides. Interiors of some plagioclase phenocrysits altered: most fresh. Hand sample appears coarse grained due to abundance ol phenocrysts and nature of groundmass.

$2178 \mathrm{AWs}-98$, leucobasalt, Mallard Duck Bay, Dal'k-gray, fine-grained leucobasalt. Glomeroporphyritic phenocrysts of plagioclase $\left(\mathrm{An}_{6} ;\right.$ ? $)$ and orthopyroxene in groundinass of plagioclase, clinopyroxene, orthopyroxene, divitrified glass, and opaque oxides. Plagioclase fresh and unaltered. Pilotaxilic lexture.

$2278 \mathrm{AWs}-111$, leucolsasalt, Kametolook River, Dark-green-browis, porphyritic leucobasall wilh fine-grained groundmass of pyroxene, plaginclase, and glass. Plagioclase (Anss) phennerysts fractured; fractures contain glass. Hyalopilitic texture. Pyroxene altered to fine-grained secondary phases. Abundant opaque mineral (magnetite?) in groundmass.

$2378 \mathrm{AWs}-134$, dacite, Chignik Island. Dark-gray, medium- to line-grained porphyritic dacite. Medium-grained phenocrysts of plagioclase $\left(\mathrm{An}_{40.4 \mathrm{~s}}\right)$ in fine-grained groundmass of plagioclase, or thopyroxene, clinopyroxene, and quartz. Some plagloclase crystals show fraclures and dislocations. Fractures filled with devitrified glass indicate proloclastic, subophitic lexture.

$2479 \mathrm{AWs}-2$, andesite, Meshik Formation. Brown-weathering, very fine grained andesite flow. Contains sparsely distributed phenocrysts of orthopyroxene, clinopyroxene, and rare plagioclase (minimum Ans 0 ) in $\{l o w$-textured groundmass of very fine grained plagioclase, amphihole or augite, and glass.

$2579 \mathrm{ADt} \cdot 23$, Rex Prospect. Propylitically altered hornblende andesile porphyry. Closely packed phenocrysts of hornblende and plagioclase $\left(A n_{s_{4}}\right)$ in groundmass of devilrified glass, plagioclase, and sericite. Most plagioclase phenocrysts parlially altered to sericite; many homblende phenocrysts partially altered to chlorite and calcite. Abundant epidote.

26 79A Dt-95, andesite, Meshik Formation. Deuterically altered hornblende-andesite porphyry, Phenocrysts of green, pleochroic hornblende in groundmass of fine-grained, anhedral plagioclase crystads ( $\mathrm{An}_{6} 6$ ? ) and devitrified glass. Small proportion ( $<5 \%$ ) of quartz crystals, some of which are subhedral or euhedral. Some hornblende altered to calcite and chlorite.

2779 ACe-20, basalt, Meshik Formation. Porphyritic, flow-textured oljvine basalt. Phenocrysts of olivine and uralized pyroxene(?) in fine-grained groundmass of plagioclase (minimum Anbz), opaque minerals, olivine, and augite(?). Olivine phenocrysts altered to iddingsite on grain boundaries, and some plagjoclase crystals have cores that appear to be chlorite or uralite.

28 R41358A, dacite, Rex Prospect. Biotite-hornblende dacite. Abundant phenocrysts of relatively fresh plagioclase, poikiolitic hornblende, and quartz in sparse groundmass of quartz, plagioclase, and minor potassium [eldspar. Minor biotite present and appears to be primary or formed in reaction relationship with hornblende; it is not hydrothermal. Hornblende has inclusions of plagioclase and quartz and shows minor replacement by chlorite. Pyrite present and concentrated around and within hornblende and biotite grains. 
rate of about $6 \mathrm{~cm} / \mathrm{yr}$.

4. Segmentation of the ridge was minor (and does not significantly affect estimates of ridge position).

I suggest that the hiatus in magmatic activity postulated by the model of DeLong and others (1978) is the lull in volcanic activity that began about $25 \mathrm{~m} . \mathrm{y}$. B.P. and separates the Meshik and Aleutian ares in the central Alaska Peninsula.

An alternative explanation for the lull in magmatic activity during middle Miocene time is cessation of subduction at the paleo-Aleutian trench, which implies migration of the Alaska Peninsula lerrane on the hasis of the coupling-migrating, decoupling-subducling assump(ion. In support of this, Stono and Packer's (1979) paleomagnetic interpretation suggested limited postFocene migration of the Alaska Peninsula.

Byme (1979) altematively suggested, on the basis of marine magnetic anomalies, a Paleocene demise for the Kula-Pacific Ridge and little or no subduction along the Alaska Peninsula during Tertiary time. However, as. suming that the existence of a volcanic arc is indicative of subduction, the $30-$ to- $40 \mathrm{~m} . \mathrm{y}$. history of volcanism for the Meshik and Aleutian arcs strongly suggests that subduction was in fact important during Teytiary time on the Alaska Peninsula.

\section{ACKNOWLEDGMENTS}

This work began in conjunction with a mineralresource-appraisal program conducted by the U.S. Geological Survey in the Chignik and Sutwik Island Quadrangles, Alaska, under the direction of R.L. Detterman. I thank the U.S. Geological Survey and Dartmouth College for support while I was a graduate student doing this work. I also thank Professor 3.B. Lyons for discussions, advice, and assistance while I was at Dartmouth. J.R. Riehle critically reviewed an early draft of the manuscript. R.L. Detterman and J.A. Wolfe commented on the manuscript, and Wes Hildreth, D.B. Stone, R.J. Motyka, and S.A. Swanson also reviewed the manuscript.

\section{REFERENCES CITED}

Brockway, Ronald, Alexander, B., Day, P., Lyle, W.M. Hiles, R., Decker, W., Polski, W., and Reed, B.L., 1975, Bristol Bay region, stratigraphic comelation section, southwest Alaska: Anchorage, The Alaska Geological Society, 1 sheet.

Burk, C.A., 1965, Geology of the Alaska Peninsula island arc and continental margin: Geological Saciety of America Mensoir 99, 250 p., scales $1: 250,000$ and $1: 500,000,2$ sheets.

Byrne, Tim, 1979, Late Paleocene demise of the Kula. Pacific spreading center: Geology, v. 7 , no. 7 , p. $341 \cdot 344$.

Cox, Allan, and Dalrymple, Q.B., 1967, Statistical analysis of geomagnetic reversal data and the precision of potassium-argon dating: Journal of Geophysical Research, v. 72, no. 10, p. 2609-2614.

Dalrymple, G.B., and Lanphere, M.A., 1969, Potas sium-argon dating, principles, techniques, and epplication to geochronology: San Francisco, W.H. Freeman, $258 \mathrm{p}$.

DeLong, S.E, Fox, P.J., and McDowell, F.W., 1978, Subduction of the Kula Ridge at the Aleutian Trench: Geologicsl Society of America Bulletin, v. 89, no. 1, p. 83.95 .

1980, Subduction of the Kula Ridge at the Aleutian Trench: Reply: Geological Society of American Bulletin, pt. 1, v. 90, no. 12, p. 700-702.

Detterman, R.L., Miller, T.P., Yount, M.E., and Wilson, F.H., 1981, Geologic map of the Chignik and Sutwik Island Quadrangles, Alaska: U.S. Geological Survey Miscellaneous Geological Investigations Map I. 1228 , scale $1: 250,000$.

Dickinson, W.R., 1968, Circum-Pacific andesite types: Journal of Geophysical Research, v. 73, no. 6, p. 2261.2269 .

Engels, U.C., and ingamells, C.O., 1970, Effect of sample inhomogenity in K.Ar dating: Geochimica et Cosmochimica $\Lambda$ cta, v. 34, p. 1007-1017.

Farrar, Edward, and Dixon, J.M., 1980, Subduction of the Kula Ridge at the Aleutian Trench: Discussion: Geological Society of America Bulletin, pt. 1, v. 90 , no. 7, p. 699-700.

Jones, D.L., Silberling, M.J., Berg, H.C., and Plafker, George, 1981, Map showing tectonostratigraphic terranes of Alaska, columnar sections, and summary description of terranes: U.S. Geological Survey Open-file Report $81.792,19 \mathrm{p}$, scale $1: 2,500,000$, 1 sheet.

Knappen, R.S., 1929, Geology and mineral resources of the Aniakchak district, in Smill, P.S., Mineral resources of Alaska, report on progress of invesligations in 1926: U.S. Geological Survey Bulletin $797 \cdot$. p. $161 \cdot 227$.

Marlow, M.S., Scholl, D.W., Buffington, E.C., and Alpha, T.R., 1973, Tectonic history of the central Aleutian arc: Geological Socicty of America Bulletin, v. 84 , no. 5, p. $1556 \cdot 1574$.

Nielson, D.R., and Stoiber, R.E., 1973, Relationship of potassium content in andesite lavas and depth to the seismic zone: Journal of Geophysical Research, v. 78 , no. 29 , p. 6887-6892.

Reed, B.L., and Lanphere, M.A., 1973, Alaska-Aleutian Range batholith: Geochronology, chemistry, and relation to circum-Pacific plutonism: Geological Society of America Bulletin, v. 84, no. 8, p. 2583 . 2610 .

Ringwood, A.E., 1977, Pelrogenesis in island arc systems, in Talwani, Manik, and Pitman. W.C., III, eds, Island arcs, deep sea trenches and back-arc basins: American Geophysical Union, Maurice Ewing Series, v. 1, p. $311 \cdot 324$.

Stone, D.B., and Packer, D.R., 1979, Paleomagnetic data from the Alaska Peninsula: Geological Society of America Bulletin, pL. 1, v. 90, no. 5, p. 545.560.

Streckeisen, Albert, 1979. Classification and nomen. clature of volcanic rocks, lamprophyres, carbona. tites, and melilitic rocks: Recommendations and suggestions of the IUGS Subcommission on the 
systematics of igneous rocks: Geology, v. 7, no. 7, p. $331 \cdot 335$,

Wahrhaftig, Clyde, 1965, Physiographic divisions of Alaska: U.S. Geological Survey Professional Paper 482, 52 p., scale $1: 2,500,000,6$ sheets.

Wilson, F.H., 1980, Late Mesozoic and Cenozoic tectonics and the age of porphyry copper prospects, Chignik and Sutwik Island Quadrangles, Alaska: U.S. Geologica! Survey Open-lile Report 80.543 , $94 \mathrm{p}$., scales $1: 250,000$ and $1: 12,000,5$ sheets. 1981, Map and lable showing radiometric ages of rocks in the Aleutian lslands and the Alaska
Peninsula: U.S. Geological Survey Open-file Report $81 \cdot 471,24$ p., scale $1: 1,000,000,1$ sheet.

Wilson, F.H., 1982, Map and tables showing preliminary results of $\mathrm{K} \cdot \mathrm{Ar}$ age studies in the Ugashik Quad. rangle, Alaska Peninsula: U.S. Geological Survey Open-rile Report $82 \cdot 140$, scale $1: 250,000,1$ sheet.

Wilson, F.H., Gaum, W.C., and Herzon, P.L., 1981, Map and lables showing geochronology and whole-rock geochemistry of the Chignik and Sutwik Island Quadrangles, Alaska: U.S. Geological Survey Miscellaneous Field Studies Map MF.1053-M, scale $1: 250,000,3$ sheets. 


\section{STAFF ${ }^{1}$}

Ross G. Schaff, State Geologist

William W. Barnwell, Deputy State Geologist

Administrative Services

,R.R, Jensen, Administralive of ficer ${ }^{2}$

.D.J. Allen. Accounting clerk

.R.F. Baird, Clerk ty pist

.P.L. Coonrod. Secretary

.D.B. Debenham, Clerk ty oisi

.E.M. Lamey, $\Lambda$ dministrative assistant

.C.L. Mahan, Accounilse technician

.C.M. Mandelin, Clerk ty plst

. R. Mlchels. Supply technician

,J.N, Newhaard, Accounting technician

C.A. Rawlinsan, Clerk ty pist

.I.E. Richards, Clerk typisi

.B.A. Syverıson. Clexk lypist

J.L. Weir. Clerk typist

.M.E. Wright Clerk ty pist

A rehaeology

R.D. Shaw, Arehaeologist ${ }^{2}$

.R.G. Buzzcll, Historian

,A.G. Dixon, Archaeologist

D.E. Gibson, Archecologist

C.E. Holmes, Archaeologist

S.L. Klingler, Axchaeologist

J.D. McMahan, Archacologist

C.W. Mishler, Historian

.D.R. Reger, Archaeologist

Data Procossing

.N.W. Crosloy, Operallons reseurch analyst ${ }^{2}$

.D.E. Anctil, Analysi programmer

.G. Finch, Natural resource technician

.B.S. Hurtie. Analyst programmer

E,L. Jenks, Data processing manager

J.D. Jurgens. Analyst progzammer

Engineering Geolngy

R.G. Updike, Geologist ${ }^{2}$

J.N. Davies, Geologist

.K.L. Krause, Geologist

.B. Ranken, Geologist

.J.W. Recder, Gcologist

.C. A. Ulery, Geological asstatant

Geochemistry

M.A. Wiltse, Chemist ${ }^{2}$

M.R. Astiwell. Minerals laboratory technician

W.B, A tencio, Chemlsi

K.B. Faris, Chemist

.M.K. Polly. Mine rals laboratory lochnician

.N.C. Veach, Chernlst

\section{Geolovic Mappine}

.R,D. Reger, Geologist ${ }^{2}$

.D.D. Adams, Geological asslstant

.M.D. Albanese, Geolodist

J.D. BJum. Geologist

.'T,K. Bundtzen, Geologist

.L.E. Burns, Geologist

.R.A. Combellick, Geologist

.J.E. Decker, Geologist

.3.T. Dillon, Geologist

.W.G. Gilbert, Geologist

D.R. Hlckmoet, Geological asststant

.J.T. Kline, Geologist

.T.A. I ittle, Geological assistant

.G.D. Mareh, Gcologist

G.H. Pessel, Geologtst

S.E. Rawlinson, Geolorist

R.R. Relfenstuhl, Geologlcal assistan

.M.S. Robingon, Geologist

.T.E. Smith, Gealogist

.D.N. Solle, Geologist
Information services

C.L. Danlels, Publications speciallst 2

.G.M, Laird, Cartographer

L.F. Larson. Publlcatlons specialist

,R.A. Mann, Clerk

.K.E. Ohlund, Clerk typist

K.S. Pearson, Carlographer

.V.L. Feger. Publications technjclan

J.S. Sapp, Clerk typlst

L.C. Schell, Cartographer

Minerals \& Energy lnvestigations

.G.R. Eakins, Coolngist ${ }^{2}$

J,G. Clough, Geologist

K.M, Goff, Geological assistant

S.A. Liss, Geolouical assistant

L.L. Lueck, Geologist

.R.D. Merzitt. Geologist

R.J. Molyka, Geolorist

.C.J. Nye, Geologist

Oll and Gas

D.L. McGee, Geologlst 2

D.L. Bertussa, Geological assistant

J,J. Hangen, Geophysicist

E.E. Harris. Geological assistant

NI.W. Herning, Geologist

S.A. Jacques, Carlographer

R.W. Kormbrath, Gcologist

D.I. Krouskop, Geophysictst

W.M. Lyle, Geologist

J,F. Meyer, Geophy siclst

C.G. Mull. Geologist

M.F. Pritchard, Cartagrapher

T.N. Smith, Geologist

S.M. Weum, Geophysiclst

.B.K. Wilson, Geological assistant

Resource Analysis

M.J. Wibbenmeyer, Natural resource manager ${ }^{3}$

E. F. Becla, Natural resource manager

.M.S. Chelsty, Geologist

K.H, Clautice, Goologist

.G. Dickison, Natural yesource manager

T.G. Johnson, Data control specialist

W.A. Potrik, Geological assistant

Water Resources

W.E. Long, Hydrologist ${ }^{2}$

R.D. Allely, Hydrologist

S.J. Carrick, Hydrologist

.E.J. Collazzi, Hydrologlst

L.L. Dearborm, Hydrologist

-M.W. Inghram, Hy drologisl

.R.W. Ireland, Hydrologlst

S.F. Mack, Hydrologist

.M, A, Maurer, Hydrologisi

D. L. Meynard, Hydrologist

M.A. Moorman, Gcologist

J.A. Munter, Hydrologist

${ }^{1}$ In addition to the permanent staff listed above. DGGS has embloyed over 100 students in the Department of Natural Resources Sludent

Intern Program.

2 Section or Unil Chief

3 Acting Section Chief. 